\title{
MODIFIED SERVQUAL MODEL AND EFFECTS OF CUSTOMER ATTITUDE AND TECHNOLOGY ON CUSTOMER SATISFACTION IN BANKING INDUSTRY: MEDIATION, MODERATION AND CONDITIONAL PROCESS ANALYSIS
}

\author{
Rizwan Raheem AHMED ${ }^{1}$, Jolita VVEINHARDT ${ }^{2}$, Dalia ŠTREIMIKIENÉ ${ }^{3}$, \\ Muhammad ASHRAF ${ }^{4}$, Zahid Ali CHANNAR ${ }^{5}$ \\ 1, ${ }^{4}$ Faculty of Management Sciences, Indus University, Block-17, \\ Gulshan, Karachi-75300, Pakistan \\ ${ }^{2}$ Faculty of Economics and Management, Vytautas Magnus University, \\ Daukanto str. 28, Kaunas, Lithuania \\ ${ }^{3}$ Vilnius University, Kaunas Faculty, Muitines 8, LT-44280 Kaunas, Lithuania \\ ${ }^{5}$ Department of Business Administration, Sindh Madressatul Islam University, \\ Karachi-74000, Pakistan \\ E-mails: ${ }^{1}$ rizwanraheemahmed@gmail.com; ${ }^{2}$ jolita.vveinhardt@gmail.com; \\ 3alia.streimikeine@khf.vu.lt (correspondingauthor); ${ }^{4}$ professycom@yahoo.com; \\ 5drzahidalic@gmail.com
}

Received 12 June 2017; accepted 13 August 2017

\begin{abstract}
Banks are very important financial services sector, and in banking sector there is an intense competition amongst the local and foreign banks throughout the world. The objective of this research is to analyse the effects of perceived value and customer trust, and role of technology in banking service qualities and customers' satisfaction in Pakistani context. For this purpose we employed modified SERVQUAL model with four dimensions such as empathy, competence, reliability, and online service. An adapted questionnaire was used to carry out this survey research, and collected 830 responses from the customers of Pakistani banking industry. We used factor analysis, confirmatory factor analysis, and bootstrapping methods to carry out this research. The results of the study demonstrated that our four-dimensional model of modified SERVQUAL has a significant impact on overall customer satisfaction. It is further concluded from the bootstrapping method that modified SERVQUAL dimensions and customer satisfaction are positively mediated by the perceived value and trust. Finally, it is also concluded that the implementation of technology serves as moderating variable in the banking sector. The outcomes of this research are beneficial to the senior management of banking sector in order to implement the effective and customised online banking structure to gain competitive advantages, and provide vibrant online banking services that enhance the standard and ease of services to the customers and earn their confidence. The originality and novelty of this research provide a significant contribution in the application of SERVQUAL model specifically for the banking service quality dimensions and customer satisfaction in marketing research.
\end{abstract}

Keywords: service quality dimensions, customer satisfaction, perceived value, trust, technology, modified SERVQUAL model, structural equation modelling, bootstrapping method.

JEL Classification: C12, G21, L80, M30. 


\section{Introduction}

The customers are the premier in any service or manufacturing industry, especially, in service industries like banking sector where customers are directly associated with the organization's services and ultimately with it's earning capacity. Customers are often very much demanding and decisive in their attitude regarding the quality of services offered by the banks; hence it is very difficult to stick customer, and it is an up hill task for banks. In order to win the customer loyalty and ensuring their interest, banks are required to uphold the long-term relationship with their customers. One of the best ways of retaining congenial customer relationship is to realize the need of customers, thereby providing satisfactory services, and however for materializing this purpose banks will have to continuously improve the quality of services. The quality service is one of the single dominating factors that assist the bank to make the difference in the arena of competition (Oskooii, Albonaiemi 2017; Berry, Thompson 1982). Service quality as a research paradigm has won the considerable confidence for both academic and corporate researchers for last two of decades. A significant number of practitioners have a strong belief that service quality can multiply the firms' productivity (Goyal, Chanda 2017; Al-Hawari 2006; Black et al. 2001; Caruana et al. 2000; Cheruiyot, Maru 2013; Haynes, Fryer 2000; Yoo, Park 2007).

Parasuraman et al. (1985) have carried out the innovative work, and first, they have conceptualized the service quality dimensions and model. Their research findings revealed 10-dimensional service quality measurement tool and developed service quality gap model. With the passage of time Parasuraman et al. (1988) shrink the service quality measurement from 10 dimensions to five dimensions. They developed 22 items based measurement scale and proposed its name as SERVQUAL model. It is an imperious claiming that the SERVQUAL model has diagnostic abilities and carrying some applied implications (Apornak 2017; Long 2016; Oskooii, Albonaiemi 2017; Parasuraman et al. 1991, 1994). The diagnostic capability of SERVQUAL model is also declared even more instrumental for banking sector service quality measurement as compared to any other measurement scale such as SERVPERF (Oskooii, Albonaiemi 2017; Angur et al. 1999). Several researchers have used the SERVQUAL model in different service industries (Apornak 2017; Long 2016; Awan et al. 2011; Chi-Cui et al. 2003; Lam, Woo 1997; Lim, Tang 2000; Raza et al. 2015; Wang et al. 2003; Yavas et al. 1997; Zhu et al. 2002). Several research studies have already been carried out to examine the association between customer satisfaction and different dimensions of service quality in various services industries (Bourne 2016; Mwatsika 2016; Arasli et al. 2005; Newman, Cowling 1996; Peterson, Wilson 1992; Rust, Oliver 1994; Taylor, Baker 1994; Woodside et al. 1989). These research studies have cropped up the mutual consensus that quality services and customer satisfaction are the most dominating components of a service industry.

Several studies have also established the positive and significant link between service quality dimensions and customer satisfaction in banking industry across the globe (Setiawan, Sayuti 2017; Gümüş, Öner 2016; Avkiran 1994; Blanchard, Galloway 1994; 
LeBlanc, Nguyen 1988). Wang et al. (2003), and Lewis and Pescetto (1996) endorse the reality that service quality is the single most dominating source of success for the banking business. Mwatsika (2016), Raza et al. (2015), Gilmore (2003), Ladhari et al. (2011), Behara et al. (2002), and Robinson (1999) have endorsed the five dimensions of SERVQUAL model of Parasuraman et al. (1985), and demonstrated the uniqueness of SERVQUAL model and its allied measurement scale in several types of services and cultures. Bahia and Nantel (2000) have proposed a six-dimensional (access, assurance, service portfolio, price, tangibles, and reliability) SERVQUAL model specifically for the measurement of banking services quality and customer satisfaction. Further, in the context of Chinese banking sector, Guo et al. (2008) have proposed the four-dimensional (communication, technology, human capital, and reliability) SERVQUAL, model. This state of affairs seems to make the researchers believe that different dimensions have novel and different outcomes in several sectors and countries. Responding to accelerate the working competition in banking industry, every bank for its existence and survival has to ensure every possible step to retain the customers. The prolong relationship with customers; service quality and banks nexus are no more secret (Rather, Sharma 2017; Caruana, Malta 2002). Customer trust, satisfaction and predictability of customer loyalty were found in an investigation (Phung 2016; Garbarino, Johnson 1999; Gustafsson et al. 2005). In the Malaysian context, the studies concluded the positive influence of customer satisfaction on image, customers' trust, and customers' loyalty, with special reference to Islamic banking (Adams et al. 2016; Amin et al. 2013; Hoq et al. 2010).

There are few studies have been carried out regarding the different mediating variables such as electronic word of mouth, perceived value, brand loyalty, customer trust and customers' satisfaction. However, the undertaken study is unique in a sense that we have measured the association of modified SERVQUAL dimensions and customers' satisfaction. We also incorporated two mediating variables such as customer trust and perceived value, and technology as moderating variable, and examined the influence of these variables in a relationship of modified SERVQUAL dimensions (empathy, reliability, competence, and online banking services) and customers' satisfaction in Pakistani commercial banking context. The reason for incorporating the online banking dimension is due to the fast paced technological innovations that keep forcing the banking system to respond positively in this direction (Bourne 2016; Abdullah, Kassim 2009). The pioneers of the SERVQUAL model narrate that technology has a significant role in shaping the customer relationship and service quality (Apornak 2017; Long 2016; Parasuraman, Grewall 2000) and recommend further investigation, and the same has been carried out in the current study.

This research study is important and significant in many folds. In this research, we have used four modified service quality dimensions for latest online banking operation system. This research with modified measurement of service quality for banks intended to capture the perceptions of customers about service quality. The questionnaire was adapted and modified according to the considered dimensions of SERVQUAL and other factors; overall 25 items of total eight factors were included in the questionnaire. Each factor has three items except online banking, which has four items. We have carried 
out this survey research from the retail banking customers of Karachi city who were also well acquainted of the online banking operations of commercial banking sector of Pakistan. Since, Karachi is the financial hub and all the banks have their head offices in Karachi, thus, the sample is good representation of overall Pakistan. The respondents of the study were asked to rate the quality service in terms of performance through various items and their link with the expectations. The four dimensions of bank service quality have been made the part of this analysis as follows:

- Dimension "empathy", evaluates the capacity, capability, and effort from the part of the bank to cater the customers' needs.

- Dimension "reliability", weighs up the bank's capability and measures has taken to render the services in a perfect manner.

- Dimension "competence", which assess the amount of commitment and intended communication from the part of bankers to the customers.

- Dimension "online banking", which assess how the online banking services are easy in use for the customers, the online banking includes the bank's ATM services, e-banking, mobile banking, and e-purse facilities etc.

The two identical intervening variables have been used, which fully mediate the relationship of quality service dimensions and customer satisfaction.

Perceived value: there is positive nexus between satisfaction and perceived value; for instance customers having the attitude that they have acquired "value for money", they would exhibit ameliorated satisfaction levels, where the customers will experience opposite who perceives otherwise.

Trust: in the coordinated relationship trust is the most pertinent factor in any working environment. In customers' point of view, the trust is an exhibition of the amount of confidence and belief on the provider of service.

In this research, we used "technology" as moderating variable between service quality dimensions and customer satisfaction. Now, today's competitive world, the services of the banks are heavily dependent on the use of sophisticated means of information and telecommunication technologies. The speed of Internet has significantly increased due to Fibre optics and processors, which made the banking operations further smooth and speedy. Similarly, in Cellular technology the Smartphone and generation telecommunication (1G-5G) have brought revolution in online transactions (Long, Vy 2016; Prasadh, Suresh 2016). Thus, the technology has a significant influence on the banking business, particularly in rendering quality services to the customers. The banking system is compelled to adopt the technological processes, and integrate its daily business regulations both locally and globally (Apornak 2017; Bourne 2016; Guo et al. 2008; Newman, Cowling 1996; Raza et al. 2015).

\section{Literature review}

In the past, several studies have been carried out on SERVQUAL dimensions; however, scholars have documented some criticism on the model. This counter analysis mainly laid emphasis on the execution and explanation of SERVQUAL measurement scale 
(Oskooii, Albonaiemi 2017; Hery 2016; Babakus, Boller 1992; Smith 1995; Newman 2001). Scholars have singled out the problems with SERVQUAL measurement scale. These scholars have found the SERVQUAL dimensions good for nothing but only for perception, anticipations and gap scores. Owing to this reality, the five dimensions of SERVQUAL are believed to be inconclusive (Apornak 2017; Carman 1990; Buttle 1996). On the contrary to this, some of the studies have used this model to strengthen the value to the SERVQUAL literature, which eventually provided sustainability to the organization in particular analysis requirements (Parasuraman et al. 1988). Even in the presence of vast criticism the ability to measure service quality through SERVQUAL model cannot be denied (Bourne 2016; Mwatsika 2016; Raza et al. 2015; Buttle 1996).

\subsection{Service quality dimensions}

The service quality concept is all encompassing, which covers both the outcomes of service and the execution process of services. According to Jovović et al. (2017), Bourne (2016), Lehtinen, U. and Lehtinen, J. R. (1991), the evaluation of customer regarding the result of service process is the service outcome. However, the end product of the execution is transferred to the customer is known as the service delivery (Parasuraman et al. 1988). The service delivery includes the way of interaction with customers, and the execution service procedures. The service quality can be defined as the kind of attitude that is exhibited due to the balance between the service anticipation and actual performance (Parasuraman et al. 1985). Earlier research studies may show consensus on the multidimensional service quality constructs, however, the results of these studies exhibited that there is no mutual agreement upon consensus pertaining to generic dimensions. For instance, a study proposed three-service quality model having three dimensions namely corporate, physical and interactive (Goyal, Chanda 2017; LeBlanc, Nguyen 1988).

On the other hand, Parasuraman et al. $(1985,1988)$ have proposed the five-dimensional (reliability, tangibility, empathy, assurance, and responsiveness) model for the measurement of service quality. In this model the tangibility refers to materialistic resources, appliances, and the manifestations of human resources; empathy describes the comprehension and being seriousness towards the needs of each customer; reliability is heavily related with the capability to provide the committed services in a perfect manner; and responsiveness indicates the bank employees' compliance to assist customers, and render timely services; whereas, assurance relates to the proficiency and capability of the system of services. A number of studies have employed the SERVQUAL model to evaluate the quality of service in numerous business concerns including banking business. Different studies (Apornak 2017; Oskooii, Albonaiemi 2017; Bourne 2016; Raza et al. 2015; Kumari, Rani 2011; Kwon, Lee 1994; Wang et al. 2003) have incorporated the SERVQUAL five dimensions model to examine the quality services and customer satisfaction in the banking sector. Several researchers have used modified SERVQUAL model, for example, Host and Knie-Anderson (2004) have incorporated price dimension in SERVQUAL model to examine the service quality in financial institutions. A new scales that measuring the quality of services in the Chinese banking sector using 
the SERVQUAL as kick-start (Guo et al. 2008). Thus, in their research, the scholars identified the modified four dimensions (reliability, communication, technology, and human capital) SERVQUAL model. Similarly, the four dimensions modified SERVQUAL model was also used to assess the service quality of Qatari Islamic banks (Abdullah, Kasim 2009).

\subsection{Service quality and banking sector}

The efficacious and efficient quality service in the banking business is known as the crucial characteristics for customer satisfaction. Hence, the quality of services has a significant role to play in promoting the sense of satisfaction among customers. Banks through effective and efficient customer relationship can win the customer loyalty, which in turn assist them to enjoy the competitive edge over business rivals (Golani 2017; Amin 2016; Berry, Thomson 1982). Similarly, Tan et al. (2016) and Teas (1993) also concluded the positive and significant association between service quality and customer satisfaction. Numerous studies have offered a solid foundation for financial institutions for uplifting the level of customer satisfaction by providing the online transactions (Oskooii, Albonaiemi 2017; Laroche, Taylor 1988; Smith, Lewis 1988, 1989; Tilston 1989; Wilkinson et al. 1991; Boaden, Dale 1994; Raza et al. 2015).

\subsection{Customer satisfaction}

A sense of satisfaction from the part of a customer, which is an outcome the quality treatment and quality services rendered. Once such provision exceeds or at least matches the anticipation of a customer, the satisfaction occurs. The literature about satisfaction postulates the theory satisfaction into two identical concepts: Transaction-specific and Cumulative satisfaction. Tan et al. (2016), Verma (2016), Olsen and Johnson (2003) describe the customers' evaluation of their occurrence with specific service or making transaction as Transaction-specific satisfaction. On the other hand cumulative satisfaction is the customers' as a whole experience with service/product over a period of time. According to Long and Vy (2016), and Gupta and Zeithaml (2006), and Zeithaml et al. (2009), the majority of the earlier studies about customer satisfaction have applied the cumulative satisfaction concept. While evaluating the quality services and its execution, if the customers perceive services beyond their expectations or at least at par to anticipation the satisfaction guaranteed, but contrary to that dissatisfaction emerges (Oliver 1980). A satisfied customer may become the brand ambassador of a bank and can exert the snowball effect on the other customers (Rather, Sharma 2017; Reichheld 1993). Literary shreds of evidence have endorsed the fact that a satisfied customer from the quality services is anticipated to tie his/her business knots with the bank for a long run (Amin 2016; Amin et al. 2011; Levesque, McDougall 1996).

\subsection{Conceptual framework for hypotheses formulation}

\subsubsection{Empathy as an SERVQUAL dimension}

The care and the personal consideration to the customer from the part of banks' staff, describe the empathy dimension of SERVQUAL (Setiawan, Sayuti 2017). According to Parasuraman et al. (1985), the empathy is characterized as care and personal consid- 
eration of a business concern makes available for its clients. It discusses the personal attention to the people working for an organization who are aware of the needs of customers and required facilities to be provided during business hours. Apornak (2017) and Parasuraman et al. (1988) acknowledge the presence of reliability and empathy as dimensions in SERVQUAL model. Moreover, Ananth et al. (2011) studied empathy in their research with special reference to private sector banks and describe the empathy as offering personal consideration and effortless execution time; which eventually exhibited into the understanding of customer needs, care, and personal attention. However, Fitzsimmons, J. A. and Fitzsimmons, M. J. (2001) opposed that the empathy includes accessibility, feelings and conscious effort to grasp the needs of customers. Johnson et al. (2002) describe empathy as efficiency to make a customer feel to be welcomed through the execution of interactive attitude from the part of the banks' staff. The SERVQUAL model signifies satisfaction that is associated with the magnitude and path to disconfirmation of an individual's exposure when she/he encounters in her/his first anticipations (Hery 2016; Prasadh, Suresh 2016; Parasuraman et al. 1985; Smith, Houston 1982; Churchill, Surprenant 1982). On the basis of earlier empirical shreds of evidence, the hypothesis of this study have been formulated as under:

$\mathbf{H}_{\mathbf{1}}$ : The empathy as the dimension of service quality has a significant and positive impact on customer satisfaction.

\subsubsection{Reliability as an SERVQUAL dimension}

The reliability signifies to the customer dealing and treatment matters that associated with the implementation of services, demonstration of services when they are being performed the first time, timely services, and maintaining error free record (Byun, Cho 2017). According to Parasuraman et al. $(1985,1988)$, the reliability is the most pivotal component in conservative services, and includes the correct order execution in the true spirit of its placement, correct records; correct quote; accurate billing; results are more authenticated than directive; and provide the promised services. Reliability is also considered more vital factor for banking services (Jovović et al. 2017; Yang et al. 2004). Parasuraman et al. (1985) in their research studied the SERVQUAL model by incorporating the data collected from four identified companies, which included banks, long distance phone companies, credit card companies, and company's maintenance services. They concluded that there was high reliability in all four companies; however, some potential exceptional values were also related to this dimension. Several researchers have used reliability as the quality dimension along with other dimensions with 22 to 30 constructs in order to investigate the customer satisfaction in conventional and Islamic banking sectors (Prasadh, Suresh 2016; Smith 1995; Jabnoun, Al-Tamimi 2003; Cronin, Taylor 1992; Raza et al. 2015). Bahia and Nantel (2000) proposed a modified SERVQUAL six dimensions (tangibility, effectiveness \& assurance, reliability, access, price, and service portfolio) model for the banking industry. Further, in the context of Chinese banking sector four-dimensional SERVQUAL model (communication, technology, reliability, and human capital) was proposed by Guo et al. (2008) to examine the service quality and customer satisfaction. On the basis of previous empirical shreds of evidence we have formulated following hypothesis for this study: 
$\mathbf{H}_{2}$ : The reliability as the dimension of service quality has a positive and significant impact on customer satisfaction.

\subsubsection{Competence as an SERVQUAL dimension}

Earlier empirical pieces of evidence provide the ample grounds that satisfaction is influenced by the competence, which can be weighed up through communication and commitment (Hery 2016). The way of responding to the needs of the customer is known as the commitment; however, communication refers for conveying the relevant information to the customer on time (Verma 2016; Kholi, Jaworski 1990). Hence competence is likely to be the innermost and fundamental expectation in the corporal link, and responding to this anticipation is considered as a predictor of satisfaction (Selnes 1998). It becomes essential for the managers in the banks that they should be vigilant regarding the factors that can improve the efficiency and competency of their subordinates (Rather, Sharma 2017; Manrai, L. A., Manrai, A. K. 2007). Staff competence can be described as having the necessary skills and acquaintance to render a particular service. It is essential for the banking staff to possess the required skill and ability to provide business consultancy to the customers whenever they needed in order to overcome financial issues of their business. Such skill of the staff to provide valued suggestions to the customers can usher the level of satisfaction among customers because customer often perceives the sense of satisfaction by comparing the outcome with their expectations. According to Selnes (1998), the competence is considered as lively interactive sessions amid customers and banks, which in turn usher the perception of shared understanding about expectations and outcomes. The greater level of staff competency leads higher level of satisfaction. The staff competency is described as integrated blend of required skill, understanding and knowledge to perform a task in a way so that quality services may render to the customers (Golani 2017; Manrai, L. A., Manrai, A. K. 2007). Thus, based on the abovediscussed literature, we have formulated following hypothesis:

$\mathbf{H}_{3}$ : The competence as the dimension of service quality has a significant positive impact on customer satisfaction.

\subsubsection{Online banking as an SERVQUAL dimension}

The fast paced access of information has transformed the traditional banking practices into the digital banking under the customers' fingertip. Thus, the customers instead of bothering physical visit to the bank; can have access to banking service of their choice whenever and wherever it is needed (Oskooii, Albonaiemi 2017). According to Jovović et al. (2017) and Dean (2002), the effective and efficient online banking service has been studied as a strong determinant of service quality dimension that provides ease of services and uplifting the level of customer satisfaction and loyalty. This quality dimension has been examined in several research studies and concluded the higher level of customer satisfaction (Rout, Samarpita 2017; Abdullah, Kassim 2009). On the basis of extensive literature review, we have included online banking dimension in existing SERVQUAL model to measure its influence on the customers' perception of the service quality and level of satisfaction in an online banking environment. In recent past studies concerning the service quality have laid more emphasis on the satisfaction 
level of a customer in several contexts. For example, a study on customer satisfaction and SERVQUAL dimensions has been conducted with special reference to the Internet banking in Pakistan (Raza et al. 2015). External and internal satisfaction of customers from the Internet banking has also been evaluated and concluded the existence of both internal and external satisfaction level among customers (Tan et al. 2016; Raza, Hanif 2013). A research while investigating the usage of e-services and its predictability of e-customer-satisfaction found that re-interpretation and re-organization of the SERVQUAL dimensions in the Internet banking practices (Zavareh et al. 2012). The use of Internet banking, ATM and fund transfer facility for $24 / 7$ services and lower transaction costs provide the competitive advantage, and offer the easiness in process execution (Adams et al. 2016; Talmor 1995; Seyal 2011). The banking business in the corporate world has taken the transition from conventional "bricks and mortar" way to online banking (Mwatsika 2016; Stehling, Moormann 2002). On the basis of above-discussed literature, we have developed the following hypothesis for this study:

$\mathbf{H}_{4}$ : Online banking as the dimension of service quality has a significant and positive impact on customer satisfaction.

\subsubsection{Perceived value and customer satisfaction}

According to Zeithaml (1988), the customer satisfaction is always backed by the perceived value; such perception develops once a customer feels that they had been provided "value for money" the higher-level satisfaction occurs contrary to that they perceive otherwise. Several studies have included perceived value as a research construct and its nature of relation with customer satisfaction (Phung 2016; Chen, Chang 2005; Glaveli et al. 2006) and found that perceived value has a direct impact on customer satisfaction level. These studies have referred the customer satisfaction as an amount of accumulated experience from the buying and consumption experience of customers. Based on earlier research studies, the perceived value has a significant and positive impact of customer satisfaction level. Higher the level of perceived value increases the higher level of customer satisfaction. Previous studies (Mwatsika 2016; McDougall, Levesque 2000; Angur et al. 1999; Andreassen, Lindestad 1998; Cronin et al. 2000) have opposed and described, the service quality often directs to perceived value that can be referred as judgment or evaluation from the customers' point of view, particularly when they compare the outcomes of services/product and their associated cost. Amin (2016), and Lovelock and Wirtz (2011) have postulated the perceived value as mediating variable between customer satisfaction and four dimensions of modified SERVQUAL related with banking business. Based afore-given literary shreds of evidence we have developed following four hypotheses:

$\mathbf{H}_{5 \mathbf{A}}$ : The empathy dimension of bank service quality and customer satisfaction will be mediated by the perceived value.

$\mathbf{H}_{\mathbf{5 B}}$ : The reliability dimension of bank service quality and customer satisfaction will be mediated by the perceived value.

$\mathbf{H}_{\mathbf{5 C}}$ : The competence dimension of bank service quality and customer satisfaction will be mediated by the perceived value. 
$\mathbf{H}_{\text {5D }}$ : The online banking dimension of bank service quality and customer satisfaction will be mediated by the perceived value.

\subsubsection{Trust and customer satisfaction}

In the working environment, trust is an instrumental component of a coordinated relationship. A service provider always needs customer's trust and assertive belief (Goyal, Chanda 2017; Garbarino, Johnson 1999). Ability, benevolence, and integrity are three peculiar identities of trust (Mcknight, Chervany 2002). The assertive belief of customers on the capability of service provider regarding the needed services to be rendered to them is the ability trait of trust. In addition to the intention of profit making, the benevolence is the degree to which the service provider is trusted to be generous to the customer. Integrity denotes the clients' confidence on the service provider to act ethically, truthful in agreement, and communicates authenticate information. Trust in banking business means the trustworthiness of bank, candidness; execute the process of services to clients with greater honesty. Studies have provided empirical shreds of evidence about the significance of trust in confidence building, loyalty and long-term customer relationship (Mwatsika 2016; Gounaris 2005; Singh, Sirdeshmukh 2000; Garbarino, Johnson 1999). In fact, the trust has a capability to uphold the prolong customer - banker relationship. A study in the context of Islamic banking, while examining the significance of trust and customer satisfaction documented that the lack of trust among customers will lead them to act reluctantly and always remain on toes to seize the business (Byun, Cho 2017; Amin 2016; Amin et al. 2013). The above extensive literature paves the way to formulate following hypotheses for this study:

$\mathbf{H}_{\mathbf{6 A}}$ : The empathy dimension of bank service quality and customer satisfaction will be mediated by the trust.

$\mathbf{H}_{\mathbf{6 B}}$ : The reliability dimension of bank service quality and customer satisfaction will be mediated by the trust.

$\mathbf{H}_{\mathbf{6 C}}$ : The competence dimension of bank service quality and customer satisfaction will be mediated by the trust.

$\mathbf{H}_{\mathbf{6 D}}$ : The online banking dimension of bank service quality and customer satisfaction will be mediated by the trust.

\subsubsection{Technology and customer satisfaction}

The commercial banking business is experiencing a swift and drastic remodelling due to the all-encompassing impact of information and telecommunication technologies (Saroha, Diwan 2017; Chen et al. 2017; Setiawan, Sayuti 2017). The radical and fast paced access to information and data processing approaches have made the banking business respond to customer services quickly with greater precisions. This state of affair has compelled the banks around the globe to alter the conventional approaches of banking with the most sophisticated state of the art systems to provide effective and efficient services then and there (Rout, Samarpita 2017). Thus, the most of the banks have developed technology compatible system to render timely and better-valued services to their customers. Expecting to prosper and grow, whereas, remaining indifferent 
and isolated to change for banking industry was a next to terrible. Thus, banking business left with no choice but to become part and parcel of an innovative culture. The digitalization has significantly influenced the banking sector across the globe. Today banks are linked globally by practicing the technological compatible process of business (Jovović et al. 2017; Angur et al. 1999). By using technology, the wider range of banking activities can be performed, and it can help the banking industry to stay competitive in the financial market. The biggest utility of rapid technology is assurance of quality services to the customers and their satisfaction (Prasadh, Suresh 2016; Gümüş, Öner 2016; Guo et al. 2008; Arasli et al. 2005; Angur et al. 1999; Herington, Weaven 2007; Metawa, Al-Mossawi 1998; Newman, Cowling 1996; Raza et al. 2015). These changes are very much volatile, therefore the banks are required to remain very much vigilant to the changes, as the technology changes in hours rather than years. For the efficient services to the customer, up to date technology is required to be implemented, which in turn assist the bank to make the difference. To respond positively banks are at regular intervals put greater investments into information telecommunication technologies such as Plastic currency, electronic clearing services, e-banking, banks on customers' palm, mobile banking, ATM services, E-Purse, electronic fund transfer, Bitcoin (the internet money) and much more. On the basis of an aforesaid discussion we have formulated following hypotheses for this study:

$\mathbf{H}_{7 \mathbf{A}}$ : The empathy as bank service quality dimension and customer satisfaction will be moderated by the Technology.

$\mathbf{H}_{7 \mathbf{B}}$ : The reliability as bank service quality dimension and customer satisfaction will be moderated by the Technology.

$\mathbf{H}_{7 \mathbf{C}}$ : The competence as bank service quality dimension and customer satisfaction will be moderated by the Technology.

$\mathbf{H}_{7 \mathbf{D}}$ : The online banking as bank service quality dimension and customer satisfaction will be moderated by the Technology.

\section{Estimations and results}

\subsection{Sample description}

Eight hundred and fifty (850) responses were collected from the banking sectors' customers who are well acquainted with the online banking operations. After careful analysis 830 responses were found complete and process able, thus, we have selected a sample size of 830 respondents. The sample size was reasonably higher than suggested by the studies for performing structural equation modelling (Anderson, Gerbing 1988). The analysis of respondents profiling was as: the response rate in terms of gender 445 $(53.61 \%)$ were male and $385(46.39 \%)$ were female. In terms of marital status, 408 (49.16\%) respondents were married, and $334(40.24 \%)$ were single, and 88 (10.60\%) were divorced. The age group of respondents was 18 to 60 years, however, in terms of age, $195(23.49 \%)$ belong to age bracket of 18-30 years, 301 (36.27\%) from 30-40 years, $225(27.11 \%)$ from $40-50$ years, and $109(13.13 \%)$ belongs to the age bracket of 50-60 years. As far as experience is concerned, we took 191 (23.01\%) respondents 
of 1-5 years experience, 297 (35.78\%) respondents have 5-10 years working experience, $237(28.55 \%)$ have $10-15$ years experience, $71(8.55 \%)$ have $15-20$ years, and 34 $(4.10 \%)$ have an experience of more than 20 years. The profile of respondents regarding qualification is as: 188 (22.65\%) have completed their high school diploma (HSC), 386 (46.51\%) completed their formal graduation degree, 179 (21.57\%) respondents completed their post graduation, and rest of $77(9.28 \%)$ acquired any professional qualification. As far as their income bracket is concerned, $131(15.78 \%)$ were in 10-30K, 257 $(30.96 \%)$ were in 30-50K, $233(28.07 \%)$ were in 50-70K, $120(14.46 \%)$ were in $70-90 \mathrm{~K}$, and rest of $89(10.72 \%)$ were in the bracket of more than $90 \mathrm{~K}$ (Pakistani Rupee in 000 ).

\subsection{Reliabilities and AVE of constructs}

According to Leech et al. (2011), and Cronbach (1951), the reliabilities should be considered excellent if ( $\alpha \geq 0.90)$, good if $(\alpha \geq 0.80)$, and satisfactory or at par the acceptability level $(\alpha \geq 0.70)$. The results of Table 1 showed that individual values of Cronbach exceed $\alpha>0.70$ in all the constructs, and composite reliabilities also crossed the minimum acceptable level $\alpha>0.70$ in all the variables, thus, our research has followed the cut-off values for confirmatory factor analysis. Moreover, the square root of average variance extracted (AVE) is greater than 0.50 , which is the basic requirement in structural equation modelling; this also validated the convergent validities of all the constructs (Fornell, Larcker 1981; Leech et al. 2011).

Table 1. Factor loadings and reliabilities

\begin{tabular}{|c|c|c|c|c|c|}
\hline Variables & Constructs & $\begin{array}{l}\text { Factor } \\
\text { Loading }\end{array}$ & $\begin{array}{c}\text { Cronbach's } \\
\text { Alpha }\end{array}$ & $\begin{array}{l}\text { Composite } \\
\text { Reliability }\end{array}$ & $\mathrm{AVE}^{*}$ \\
\hline \multirow{3}{*}{$\begin{array}{l}\text { Customer } \\
\text { satisfaction }\end{array}$} & $\mathrm{CS} 1$ & 0.788 & \multirow{3}{*}{0.783} & \multirow{3}{*}{0.785} & \multirow{3}{*}{0.764} \\
\hline & $\mathrm{CS} 2$ & 0.754 & & & \\
\hline & $\mathrm{CS} 2$ & 0.813 & & & \\
\hline \multirow[t]{3}{*}{ Empathy } & EMP1 & 0.731 & \multirow{3}{*}{0.745} & \multirow{3}{*}{0.765} & \multirow{3}{*}{0.745} \\
\hline & EMP2 & 0.722 & & & \\
\hline & EMP3 & 0.801 & & & \\
\hline \multirow[t]{3}{*}{ Reliability } & REL1 & 0.812 & \multirow{3}{*}{0.813} & \multirow{3}{*}{0.815} & \multirow{3}{*}{0.799} \\
\hline & REL2 & 0.800 & & & \\
\hline & REL3 & 0.831 & & & \\
\hline \multirow[t]{3}{*}{ Competence } & COM1 & 0.745 & \multirow[t]{3}{*}{0.739} & \multirow[t]{3}{*}{0.748} & \multirow[t]{3}{*}{0.738} \\
\hline & COM2 & 0.765 & & & \\
\hline & COM3 & 0.701 & & & \\
\hline \multirow[t]{4}{*}{ Online banking } & OB1 & 0.811 & \multirow{4}{*}{0.795} & \multirow{4}{*}{0.810} & \multirow{4}{*}{0.769} \\
\hline & OB2 & 0.781 & & & \\
\hline & OB3 & 0.810 & & & \\
\hline & OB4 & 0.767 & & & \\
\hline
\end{tabular}


End of Table 1

\begin{tabular}{|c|c|c|c|c|c|}
\hline Variables & Constructs & $\begin{array}{l}\text { Factor } \\
\text { Loading }\end{array}$ & $\begin{array}{l}\text { Cronbach's } \\
\text { Alpha }\end{array}$ & $\begin{array}{l}\text { Composite } \\
\text { Reliability }\end{array}$ & AVE* \\
\hline \multirow[t]{3}{*}{ Perceived value } & PV1 & 0.818 & \multirow{3}{*}{0.819} & \multirow{3}{*}{0.822} & \multirow{3}{*}{0.778} \\
\hline & PV2 & 0.855 & & & \\
\hline & PV3 & 0.800 & & & \\
\hline \multirow[t]{3}{*}{ Trust } & TRU1 & 0.826 & \multirow{3}{*}{0.802} & \multirow{3}{*}{0.799} & \multirow{3}{*}{0.755} \\
\hline & TRU2 & 0.732 & & & \\
\hline & TRU3 & 0.801 & & & \\
\hline \multirow[t]{3}{*}{ Technology } & TEC1 & 0.701 & \multirow{3}{*}{0.717} & \multirow{3}{*}{0.721} & \multirow{3}{*}{0.701} \\
\hline & TEC2 & 0.732 & & & \\
\hline & TEC3 & 0.711 & & & \\
\hline
\end{tabular}

Note: * Average variance extracted.

\subsection{Convergent and discriminant validity}

The results of Table 1 showed that the factor loading of each item is less than 0.85 and greater than 0.40 , thus the requirement of discriminant validity has met, which is also the essential condition for the structural equation modelling (Rutherford et al. 1988; Huang et al. 2004; Mishra 2016; Hsieh, Hiang 2004). It is further demonstrated from Table 4, the each pair of construct and factor has the correlation more than 0.50 , so, it justified the exclusivity of constructs for the convergent validity. The results of individual average variance extracted (AVE) also showed that each item has a value more than 0.50 as showed in Table 1, thus, it is further validated the convergent validity of each construct (Fornell, Larcker 1981; Kline et al. 2000).

\subsection{Bartlett's and Kaiser-Meyer-Olkin (KMO) tests}

Table 2 exhibited the results of KMO and Bartlett's sampling adequacy and Sphericity measurement. The results of Table 2 has exhibited the KMO value for all the items 0.859 , which means $85.90 \%$, and well above the benchmark of 0.5 or $50 \%$, which confirms the identical differences in correlation and identity matrix (Leech et al. 2011). The probability is less than $1 \%(\mathrm{p}<0.01)$ of Bartlett's test as depicted in Table 2 that shows the significance of Sphericity of Bartlett's test, and confirms that the sample for this study is ideal for factor analysis (Bartlett's 1954).

Table 2. Results of KMO and Bartlett's tests

\begin{tabular}{|c|c|c|}
\hline \multicolumn{2}{|c|}{ Kaiser-Meyer-Olkin measure of sampling adequacy } & 0.859 \\
\hline \multirow{3}{*}{ Bartlett's test of Sphericity } & Approx. Chi-square & 8200.089 \\
\hline & Df & 28 \\
\hline & Sig. & 0.0000 \\
\hline
\end{tabular}




\subsection{Total variance explanation}

The total variance explained is employed in order to elucidate the variance partition among potential variables. The Eigenvalues are used to evaluate the usefulness of factor as a general criterion. The threshold of the eigenvalue is greater than 1.0 for all factors. In our case, the eigenvalue is more than 1.0, which authenticates the significance of the factors in our study. Table 3 shows the output of total variance explained; the results show that the cumulative variance by the eight factors in our study is 100 percent, and minimum cumulative variance is 74.554 percent, which is an ideal and very good because the cut-off value should be more than 50 percent for minimum cumulative variance. Thus, all the factors have been retained for undertaken study.

Table 3. Results of variance explained

\begin{tabular}{|c|c|c|c|c|c|c|c|c|c|}
\hline \multirow{2}{*}{ 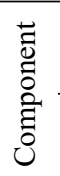 } & \multicolumn{3}{|c|}{ Initial Eigenvalues } & \multicolumn{3}{|c|}{$\begin{array}{l}\text { Extraction sums of squared } \\
\text { loadings }\end{array}$} & \multicolumn{3}{|c|}{$\begin{array}{c}\text { Rotation sums of squared } \\
\text { loadings }\end{array}$} \\
\hline & Total & $\begin{array}{l}\% \text { of } \\
\text { Variance }\end{array}$ & $\begin{array}{l}\text { Cumula- } \\
\text { tive } \%\end{array}$ & Total & $\begin{array}{l}\% \text { of } \\
\text { Variance }\end{array}$ & $\begin{array}{l}\text { Cumula- } \\
\text { tive } \%\end{array}$ & Total & $\begin{array}{l}\% \text { of } \\
\text { Variance }\end{array}$ & $\begin{array}{l}\text { Cumula- } \\
\text { tive } \%\end{array}$ \\
\hline 1 & 5.964 & 74.554 & 74.554 & 5.964 & 74.554 & 74.554 & 5.927 & 74.086 & 74.086 \\
\hline 2 & 1.008 & 12.602 & 87.156 & 1.008 & 12.602 & 87.156 & 1.046 & 13.070 & 87.156 \\
\hline 3 & 0.370 & 4.626 & 91.783 & & & & & & \\
\hline 4 & 0.221 & 2.759 & 94.542 & & & & & & \\
\hline 5 & 0.149 & 1.863 & 96.405 & & & & & & \\
\hline 6 & 0.130 & 1.629 & 98.034 & & & & & & \\
\hline 7 & 0.112 & 1.397 & 99.431 & & & & & & \\
\hline 8 & 0.045 & 0.569 & 100.000 & & & & & & \\
\hline
\end{tabular}

Extraction method: Principal component analysis.

\subsection{Factor analysis}

For the validation of all the items in independent (exogenous) and dependent (endogenous) variables we employed factor analysis. The factor analysis transmits the usefulness to shorten the larger set of information into small influences. Thus, for this purpose, we have used principal components technique with Varimax rotation method (Ali et al. 2015; Raza et al. 2015). A questionnaire having 25 items in total in our modified SERVQUAL model, customer satisfaction, mediating (perceived value \& trust) and moderating (technology) variables have been categorized into eight groups of items. The results of this study displayed in Table 4, which show that correlation for each set of an item is greater than 0.50 . These results are practically ideal and considered as significant for the factor analysis (Kaiser 1974). Table 4 exhibited the comprehensive output of principal component analysis. 
Table 4. Results of Principal component analysis

\begin{tabular}{|c|c|c|c|c|c|c|c|c|c|}
\hline Variables & $\begin{array}{c}\text { Operational } \\
\text { variables }\end{array}$ & $\mathrm{CS}$ & EMP & REL & $\mathrm{COM}$ & OB & PV & TRU & TEC \\
\hline \multirow{3}{*}{$\begin{array}{l}\text { Customer } \\
\text { satisfaction }\end{array}$} & $\mathrm{CS} 1$ & 0.65 & & & & & & & \\
\hline & $\mathrm{CS} 2$ & 0.71 & & & & & & & \\
\hline & $\mathrm{CS} 3$ & 0.69 & & & & & & & \\
\hline \multirow{3}{*}{ Empathy } & EMP1 & & 0.59 & & & & & & \\
\hline & EMP2 & & 0.68 & & & & & & \\
\hline & EMP3 & & 0.72 & & & & & & \\
\hline \multirow{3}{*}{ Reliability } & REL1 & & & 0.82 & & & & & \\
\hline & REL2 & & & 0.55 & & & & & \\
\hline & REL3 & & & 0.66 & & & & & \\
\hline \multirow{3}{*}{ Competence } & COM1 & & & & 0.73 & & & & \\
\hline & COM2 & & & & 0.71 & & & & \\
\hline & COM3 & & & & 0.67 & & & & \\
\hline \multirow{4}{*}{ Online banking } & OB1 & & & & & 0.70 & & & \\
\hline & $\mathrm{OB} 2$ & & & & & 0.63 & & & \\
\hline & OB3 & & & & & 0.57 & & & \\
\hline & OB4 & & & & & 0.60 & & & \\
\hline \multirow{3}{*}{ Perceived value } & PV1 & & & & & & 0.79 & & \\
\hline & PV2 & & & & & & 0.69 & & \\
\hline & PV3 & & & & & & 0.81 & & \\
\hline \multirow{3}{*}{ Trust } & TRU1 & & & & & & & 0.64 & \\
\hline & TRU2 & & & & & & & 0.78 & \\
\hline & TRU3 & & & & & & & 0.71 & \\
\hline \multirow{3}{*}{ Technology } & TEC1 & & & & & & & & 0.61 \\
\hline & TEC2 & & & & & & & & 0.58 \\
\hline & TEC3 & & & & & & & & 0.57 \\
\hline
\end{tabular}

\subsection{Fit measures}

According to Balakrishnan et al. (2016) and Meyers et al. (2006), there are more than 20 fit indices and no agreement which to report for measuring the hypothesized model. According to Balakrishnan et al. (2016), Ryu (2014), and Byrne (2009), these measures have been characterized into four indices categories such as: 1) absolute fit index, 2) Relative fit index, 3) Noncentrality based index and 4) Parsimonious fit index. Complete cut off results for the considered indices of this study have been reported in Table 5 . 


\subsection{Confirmatory factor analysis}

According to Balakrishnan et al. (2016) and Rutherford et al. (1988), the results of Confirmatory factor analysis, which were tested on the basis of a theory for all the factors and indicators presented in Table 5. The summarized CFA results of all the 25 constructs of measured and structural models have followed the limit for all the used indices. We have used a structural model for banking service quality in order to examine the parameters. In banking service quality (SERVQUAL) model we used four dimensions (reliability, empathy, competence, and online banking) as independent variables, moreover, we incorporated two mediating variables such as perceived value and trust, and we also used technology as moderating variable. We examine the impact of all these variables on customer satisfaction (dependent variable). Figure 1 is the graphical (AMOS) representation of structural model for this research study.

We used three indicators for customer satisfaction, three indicators for each empathy, competence, and reliability. However, we used four indicators for online banking dimension. In mediating and moderating variables we used three indicators for each perceived value, trust, and technology respectively. The multidimensionality of quality service model has necessitated, applying structural equation modelling (SEM), besides that the model has its sub-dimensions, which have been analyzed by SEM. The results of a goodness of fit indices for the measurement and structural models for this study have been reported in Table 5. The results of Table 5 exhibited that both models are statistically significant, and indices GFI, NFI, TLI, CFI, RMSEA, PCFI and PNFI values are followed the cut-off or threshold values. The output reports all the 25 items of the CFA were fit enough to sample data.

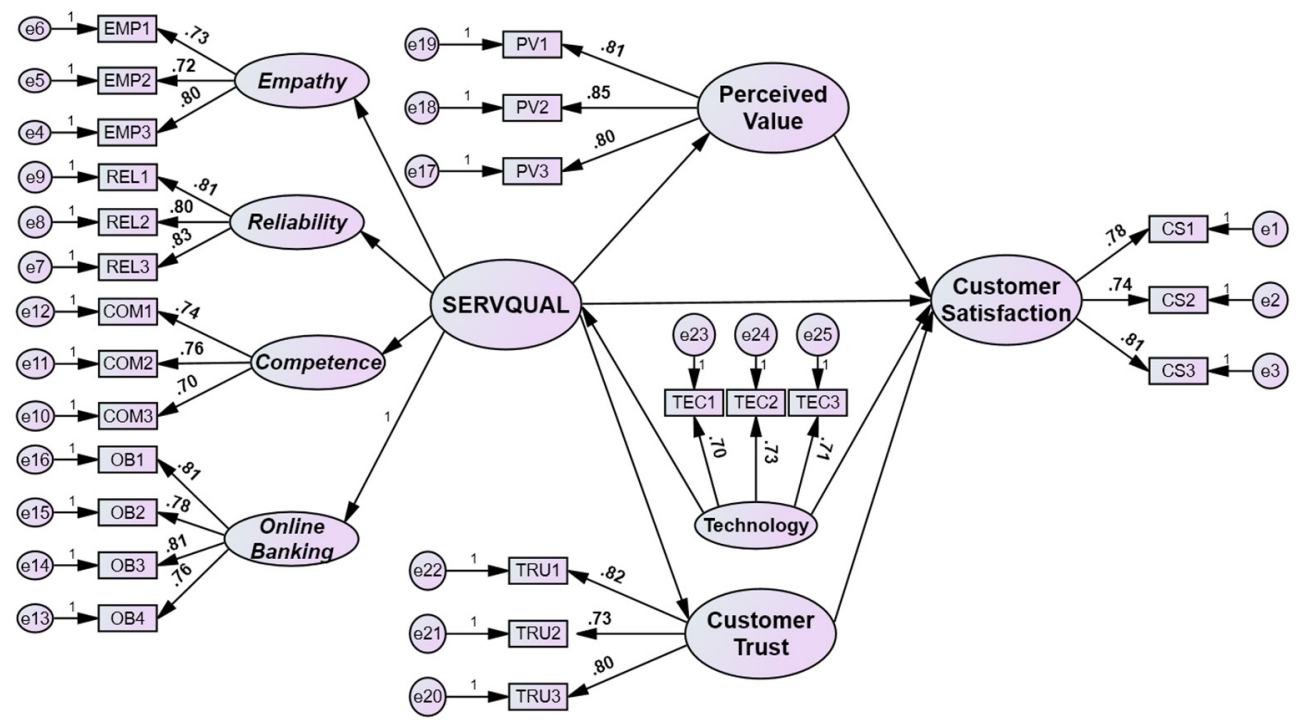

Fig. 1. Graphical (AMOS) representation of structural model of the study 
Table 5. Models fit statistics

\begin{tabular}{cccccccc}
\hline $\begin{array}{c}\text { Goodness of fit } \\
\text { measures }\end{array}$ & GFI & NFI & TLI & CFI & RMSEA & PCFI & PNFI \\
\hline Measurement model & 0.959 & 0.912 & 0.965 & 0.959 & 0.041 & 0.79 & 0.82 \\
Structural model & 0.982 & 0.951 & 0.991 & 0.979 & 0.003 & 0.86 & 0.89 \\
$\begin{array}{c}\text { Criterion (threshold } \\
\text { values) }\end{array}$ & $>0.95$ & $>0.90$ & $>0.95$ & $\geq 0.95$ & $\leq 0.05$ & $>0.75$ & $>0.75$ \\
\hline
\end{tabular}

Notes: $\mathrm{CFI}=$ Comparative fit index; NFI $=$ Normed fixed index; TLI $=$ Tucker-Lewis index; GFI $=$ Goodness of fit index; RMSEA $=$ Root mean square error of approximation; PNFI $=$ Parsimonyadjusted normed fit index; PCFI $=$ Parsimony-adjusted fit index.

\subsection{SERVQUAL dimensions and customer satisfaction (direct effect)}

Table 6 shows the output of standardized parameters and related significant values for the hypothesized association. The results ascertained that all four dimensions of modified SERVQUAL model significantly and positively influence on the customer satisfaction in banking sector of Pakistan. The outcome of analysis shows that the coefficient value of reliability is the highest among all, which is 0.692 , this finding endorses the results of Haron et al. (1994). This authenticates the evidence that customer perception is associated with the implementation of services, demonstration of services, timely services, and maintaining error free record. The online banking (0.408) is the second most significant factor, which is associated with the customer satisfaction, and followed by the competence (0.335), and empathy (0.294). The summary of the results of the hypothesized results $\left(\mathrm{H}_{1}-\mathrm{H}_{4}\right)$ exhibited that null hypotheses $\mathrm{H}_{1}, \mathrm{H}_{2}, \mathrm{H}_{3}$, and $\mathrm{H}_{4}$ have been rejected because $(\mathrm{p}<0.05 \& \mathrm{~T}>2)$, and effects $(\beta \mathrm{s})$ for the service quality dimensions (empathy, reliability, competence, and online banking) lie between LLCIs and ULCIs. Hence, it is concluded that the decisions for all the null hypotheses $\mathrm{H}_{1}, \mathrm{H}_{2}, \mathrm{H}_{3}$, and $\mathrm{H}_{4}$ have been supported, and finally concluded that empathy, reliability, competence and online banking have significant positive impact on customer satisfaction. The results of

Table 6. Hypotheses testing summary for direct effect

\begin{tabular}{|c|c|c|c|c|c|c|c|c|c|}
\hline \multicolumn{3}{|c|}{ Direct Relationship } & \multirow{2}{*}{$\begin{array}{c}\text { Effect }(\beta) \\
0.2944\end{array}$} & \multirow{2}{*}{$\frac{\mathrm{SE}}{0.0320}$} & \multirow{2}{*}{$\frac{\mathrm{T}}{9.2035}$} & \multirow{2}{*}{$\frac{P}{0.00}$} & \multirow{2}{*}{$\begin{array}{c}\text { LLCI } \\
0.2316\end{array}$} & \multirow{2}{*}{$\begin{array}{c}\text { ULCI } \\
0.3572\end{array}$} & \multirow{2}{*}{$\begin{array}{c}\text { Decision } \\
\text { Supported }\end{array}$} \\
\hline $\mathrm{H}_{1}: \mathrm{EMP} \dagger$ & $\rightarrow$ & $\begin{array}{l}\text { Customer } \\
\text { satisfaction }\end{array}$ & & & & & & & \\
\hline $\mathrm{H}_{2}: \mathrm{REL} \uparrow$ & $\rightarrow$ & $\begin{array}{l}\text { Customer } \\
\text { satisfaction }\end{array}$ & 0.6923 & 0.0239 & 28.9676 & 0.00 & 0.6454 & 0.7393 & Supported \\
\hline $\mathrm{H}_{3}: \mathrm{COM} \uparrow$ & $\rightarrow$ & $\begin{array}{l}\text { Customer } \\
\text { satisfaction }\end{array}$ & 0.3353 & 0.0297 & 11.2749 & 0.00 & 0.2769 & 0.3937 & Supported \\
\hline $\mathrm{H}_{4}: \mathrm{OB} \uparrow$ & $\rightarrow$ & $\begin{array}{l}\text { Customer } \\
\text { satisfaction }\end{array}$ & 0.4079 & 0.0232 & 17.5842 & 0.00 & 0.3624 & 0.4534 & Supported \\
\hline
\end{tabular}

Notes $: \dagger=$ Predictor; DV $=$ Customer satisfaction; $\mathrm{EMP}=$ Empathy REL $=$ Reliability COM = Competence; $\mathrm{OB}=$ Online banking. 
study are in congruence with the past research findings (Rather, Sharma 2017; Adams et al. 2016; Long 2016; Amin, Isa 2008; Anderson, Sullivan 1993; Arasli et al. 2005; Awan et al. 2011; Haron et al. 1994; Levesque, McDougall 1996; Othman, Owen 2002; Raza et al. 2015; Taylor, Baker 1994).

\subsection{Indirect effect (mediation) analysis (bootstrapping method)}

For the measurement of indirect effect (mediation analysis), we employed bootstrapping method (Hayes 2012, 2013). The relationship between services quality (SERVQUAL) dimensions (empathy, reliability, competence, and online banking) and customer satisfaction is mediated by the perceived value and trust. The results of Table 7 exhibited that empathy dimension and customer satisfaction are mediated by the perceived value and trust because zero does not lie between Boot LLCIs and Boot ULCIs. The reliability and competence dimensions and customer satisfaction is mediated by the perceived value, and online banking dimension and customer satisfaction are mediated by the perceived value and trust because the zero does not lie between Boot LLCIs and Boot ULCIs. Hence, the decisions of null hypotheses $\mathrm{H}_{5 \mathrm{~A}}, \mathrm{H}_{6 \mathrm{~A}}, \mathrm{H}_{5 \mathrm{~B}}, \mathrm{H}_{5 \mathrm{C}}, \mathrm{H}_{5 \mathrm{D}}$, and $\mathrm{H}_{6 \mathrm{D}}$ have been supported. However, the decisions of the null hypotheses $\mathrm{H}_{6 \mathrm{~B}}$ and $\mathrm{H}_{6 \mathrm{C}}$ do not support. Thus, it is finally, concluded that empathy and online banking dimensions and customer satisfaction are positively mediated by the perceived value and trust. However, the reliability and competence dimensions and customer satisfaction is mediated by the perceived value.

Table 7. Mediating effects (bootstrapping method)

\begin{tabular}{|c|c|c|c|c|c|c|}
\hline \multicolumn{7}{|c|}{ Indirect effect of Empathy on Customer satisfaction } \\
\hline Hypotheses & Mediators & $\begin{array}{c}\text { Indirect } \\
\text { effect }\end{array}$ & Boot SE & $\begin{array}{l}\text { Boot } \\
\text { LLCI }\end{array}$ & $\begin{array}{l}\text { Boot } \\
\text { LLCI }\end{array}$ & Results \\
\hline $\mathrm{H}_{5 \mathrm{~A}}:$ & Perceived value & 0.5089 & 0.0285 & 0.4535 & 0.5667 & Significant \\
\hline $\mathrm{H}_{6 \mathrm{~A}}:$ & Trust & 0.0046 & 0.0023 & 0.0012 & 0.0110 & Significant \\
\hline & Total indirect effect & 0.5135 & 0.0285 & 0.4583 & 0.5715 & \\
\hline \multicolumn{7}{|c|}{ Indirect effect of Reliability on Customer satisfaction } \\
\hline $\mathrm{H}_{5 \mathrm{~B}}:$ & Perceived value & 0.1837 & 0.0204 & 0.1467 & 0.2264 & Significant \\
\hline $\mathrm{H}_{6 \mathrm{~B}}:$ & Trust & -0.0008 & 0.0053 & -0.0118 & 0.0088 & Insignificant \\
\hline & Total indirect effect & 0.1829 & 0.0209 & 0.1443 & 0.2268 & \\
\hline \multicolumn{7}{|c|}{ Indirect effect of Competence on Customer satisfaction } \\
\hline $\mathrm{H}_{5 \mathrm{C}}:$ & Perceived value & 0.5193 & 0.0281 & 0.4676 & 0.5753 & Significant \\
\hline $\mathrm{H}_{6 \mathrm{C}}:$ & Trust & 0.0041 & 0.0032 & -0.0023 & 0.0106 & Insignificant \\
\hline & Total indirect effect & 0.5234 & 0.0281 & 0.4721 & 0.5803 & \\
\hline \multicolumn{7}{|c|}{ Indirect effect of Online banking on Customer satisfaction } \\
\hline $\mathrm{H}_{5 \mathrm{D}}:$ & Perceived value & 0.3887 & 0.0206 & 0.3497 & 0.4296 & Significant \\
\hline \multirow[t]{2}{*}{$\mathrm{H}_{6 \mathrm{D}}:$} & Trust & 0.0044 & 0.0020 & 0.0013 & 0.0098 & Significant \\
\hline & Total indirect effect & 0.3931 & 0.0206 & 0.3539 & 0.4347 & \\
\hline
\end{tabular}




\subsection{Moderating effect of technology}

The results of Table 8, exhibited the significant impact of technology as moderating variable. The multiplicative effects of the service quality dimensions (empathy, reliability, competence, and online banking) and the technology showed the significant effects because the corresponding coefficients lie between the corresponding LLCIs and ULCIs, and respective probabilities are less than 0.05 (Hayes 2013). Thus, the null hypotheses $\mathrm{H}_{7 \mathrm{~A}}, \mathrm{H}_{7 \mathrm{~B}}, \mathrm{H}_{7 \mathrm{C}}$, and $\mathrm{H}_{7 \mathrm{D}}$ have been rejected, and decisions are in supporting. Hence, it is further concluded that the technology has a significant impact as moderating variable between the services quality dimensions (empathy, reliability, competence, and online banking) and customer satisfaction. These results are consistent with the previous research studies, which demonstrated that banking services are now linked globally by using technologically compatible regulations (Rout, Samarpita 2017; Prasadh, Suresh 2016; Raza, Hanif 2013; Angur et al. 1999).

Table 8. Moderating effect of technology

\begin{tabular}{|c|c|c|c|c|c|c|c|c|}
\hline \multicolumn{9}{|c|}{ Moderating effect of technology between Empathy and Customer satisfaction } \\
\hline $\begin{array}{l}\text { Hypoth- } \\
\text { eses }\end{array}$ & Moderator & Moderation & $\begin{array}{l}\text { Coef- } \\
\text { ficient }\end{array}$ & SE & $\mathrm{T}$ & $\mathrm{P}^{*}$ & LLCI & ULCI \\
\hline $\mathrm{H}_{7 \mathrm{~A}}:$ & Technology & EMP $\times$ TEC & -0.2143 & 0.0121 & -17.7388 & 0.0000 & -0.2380 & -0.1906 \\
\hline \multicolumn{9}{|c|}{ Moderating effect of technology between Reliability and Customer satisfaction } \\
\hline $\mathrm{H}_{7 \mathrm{~B}}:$ & Technology & REL $x$ TEC & -0.0548 & 0.0117 & -4.6689 & 0.0000 & -0.0779 & -0.0318 \\
\hline \multicolumn{9}{|c|}{ Moderating effect of technology between Competence and Customer satisfaction } \\
\hline $\mathrm{H}_{7 \mathrm{C}}:$ & Technology & COM $\times$ TEC & -0.1461 & 0.0130 & -11.2210 & 0.0000 & -0.1716 & -0.1205 \\
\hline \multicolumn{9}{|c|}{ Moderating effect of technology between Online Banking and Customer satisfaction } \\
\hline $\mathrm{H}_{7 \mathrm{D}}:$ & Technology & OB $\mathrm{x}$ TEC & -0.1584 & 0.0118 & -13.4124 & 0.0000 & -0.1816 & -0.1352 \\
\hline
\end{tabular}

\subsection{R-square increment}

As showed by the Table 9, the values of R-square increased due to the interaction of the moderating variable (technology) (Hayes 2013). The significant impact of technology also exhibited by the corresponding probabilities $(\mathrm{p}<0.05)$ of moderation.

Table 9. Increment in R-square

\begin{tabular}{cccccc}
\hline Moderation & $\mathrm{R}^{2}$-changed & $\mathrm{F}$ & $\mathrm{df1}$ & $\mathrm{df2}$ & $\mathrm{P}^{*}$ \\
\hline EMP x TEC & 0.0709 & 314.66 & 1 & 826 & 0.0000 \\
\hline REL $\times$ TEC & 0.0037 & 21.79 & 1 & 826 & 0.0000 \\
\hline COM x TEC & 0.0298 & 125.91 & 1 & 826 & 0.0000 \\
\hline OB $\times$ TEC & 0.0396 & 179.89 & 1 & 826 & 0.0000 \\
\hline
\end{tabular}

Note: ' $\mathrm{X}$ ' is known as the multiplicative sign; *denotes rejection of the hypothesis at the $5 \%$ level $(\mathrm{P}<0.05)$. 


\subsection{Condithional effect of technology (moderator)}

Conditional effect of technology (moderator) between service quality dimensions (empathy, reliability, competence, and online banking) and customer satisfaction have displayed in Table 10. The first column of the Table 10 demonstrated the different quantitative moderating (technology) variable's values that are mean plus/minus one standard deviation from the mean, which corresponds to the $25^{\text {th }}, 50^{\text {th }}$, and $75^{\text {th }}$ percentiles of the distribution of technology scale in the sample at $95 \%$ confidence interval. The conditional effects suggested that the service quality dimensions (reliability, empathy, competence, and online banking) and customer satisfaction at three values of technology (moderator) is significant because the effects lie between LLCI and ULCI, and $\mathrm{p}<$ 0.05 (Hayes 2013).

Table 10. Conditional effect

\begin{tabular}{ccccccc}
\hline \multicolumn{7}{c}{ Predictor: Empathy } \\
\hline Technology & Effect & SE & T & $P^{*}$ & LLCI & ULCI \\
\hline 2.7139 & 0.6092 & 0.0293 & 20.7899 & 0.0000 & 0.5517 & 0.6667 \\
\hline 3.7783 & 0.3811 & 0.0306 & 12.4614 & 0.0000 & 0.3211 & 0.4411 \\
\hline 4.8427 & 0.1529 & 0.0366 & 4.1743 & 0.0000 & 0.0810 & 0.2249 \\
\hline 2.7139 & 0.7096 & 0.0198 & 35.8257 & 0.0000 & 0.6708 & 0.7485 \\
\hline 3.7783 & 0.6513 & 0.0238 & 27.3630 & 0.0000 & 0.6046 & 0.6980 \\
\hline 4.8427 & 0.5929 & 0.0325 & 18.2715 & 0.0000 & 0.5292 & 0.6566 \\
\hline 2.7139 & 0.5570 & 0.0265 & 20.9863 & 0.0000 & 0.5049 & 0.6091 \\
\hline 3.7783 & 0.4016 & 0.0296 & 13.5449 & 0.0000 & 0.3434 & 0.4598 \\
\hline 4.8427 & 0.2461 & 0.0379 & 6.4916 & 0.0000 & 0.1717 & 0.3205 \\
\hline & & Predictor: Reliability & & \\
\hline 2.7139 & 0.5915 & 0.0240 & 24.6127 & 0.0000 & 0.5443 & 0.6387 \\
\hline 3.7783 & 0.4229 & 0.0286 & 14.7800 & 0.0000 & 0.3667 & 0.4790 \\
\hline 4.8427 & 0.2543 & 0.0371 & 6.8548 & 0.0000 & 0.1815 & 0.3271 \\
\hline
\end{tabular}

Notes: * denotes rejection of the hypothesis at the 0.05 level $(\mathrm{P}<0.05)$; Level of confidence for all confidence intervals in output: 95.00; Values for quantitative moderators are the mean and plus/minus one SD from mean.

\subsection{Visualization of conditional effect}

Figure 2 showed the visualizing conditional effect of a moderator (technology) between service quality dimensions (empathy, reliability, competence, and online banking) and customer satisfaction. The 3D plots show that all the quality dimensions such as empathy, reliability, competence, and online banking, and customer satisfaction experienced significant impact while we incorporated the technology as moderating variable. The 
impact of customer satisfaction changes with the changes in values of the technology as depicted in Figure 2. According to Hayes (2013), the graphical plot of moderating effect is an essential condition because it clarifies the impact of moderating impact. The changes in moderating variable cause changes on the dependent variable (Hayes 2013). In Figure 2, the "Purple" colour shows the technology (moderating variable), "Red" colour shows the service quality dimensions (empathy, reliability, competence, and online banking), and the "Orange" colour depicted the customer satisfaction (dependent variable). Thus, it is evident from the $3 \mathrm{D}$ plot that there is a significant effect of technology between service quality dimensions and customer satisfaction because at every reading of technology, the customer satisfaction level is different, and it changes with the change of technology readings.
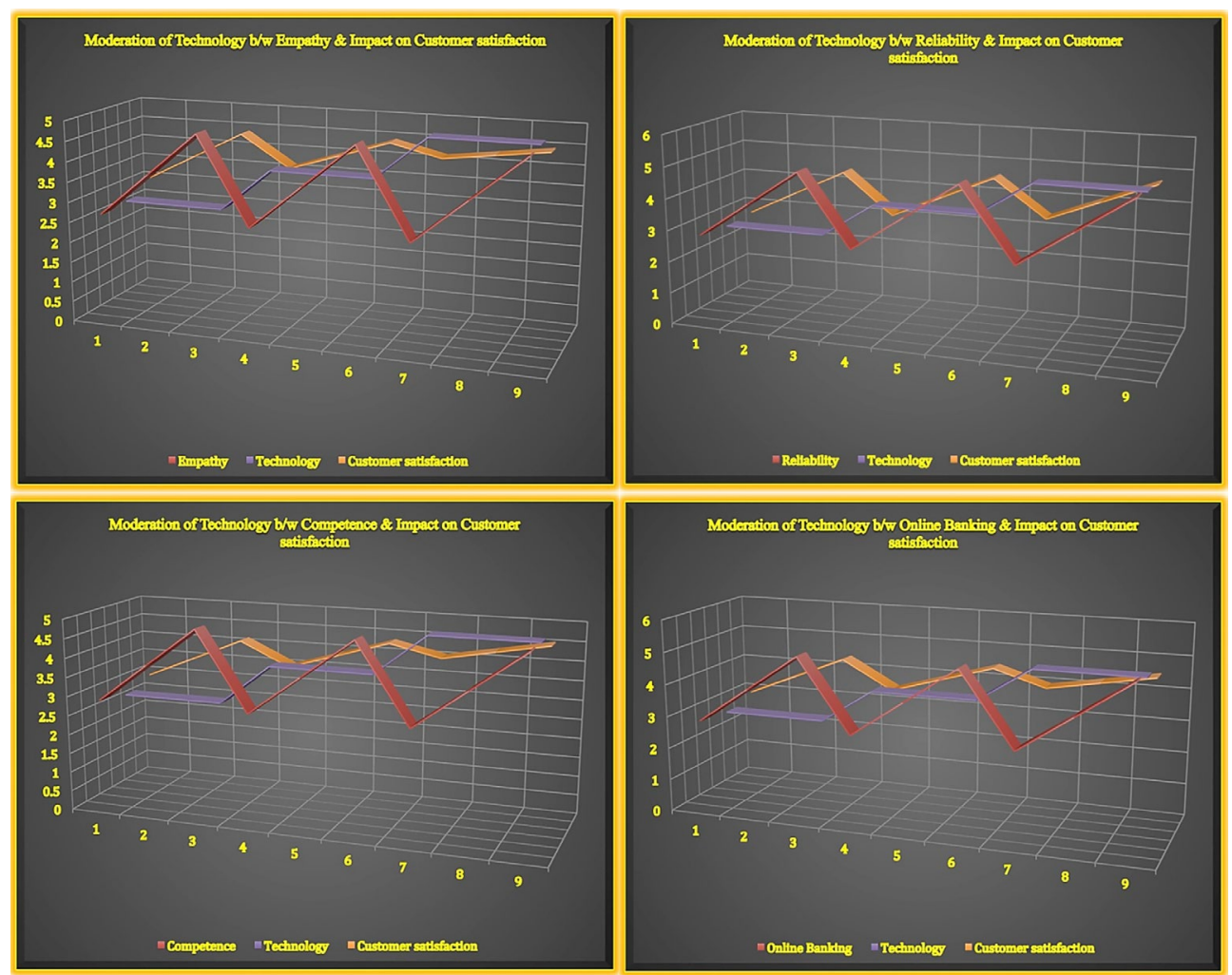

Fig. 2. 3D plots of the interaction of service quality dimensions with technology and visualizing conditional impact on customer satisfaction

\section{Conclusions}

We have examined the nature of a relationship between service quality dimensions (empathy, reliability, competence, and online banking) and customer satisfaction by using modified SERVQUAL model in commercial banking sector of Pakistan. A data collection instrument having 25 items with careful modification has been adapted for this 
study. The results of the study concluded that the four identical dimensions (empathy, reliability, competence and online banking) of service quality (modified SERVQUAL) have a significant positive impact on customer satisfaction. It was found that coefficient value of reliability dimension was 0.692 , the highest among all dimensions of service quality; the results of this study confirm that service quality along with all four dimensions carries consistent reliability and each of them is significantly and positively related to conventional banking service quality dimensions. The results also indicated that the service quality dimensions such as empathy, reliability, competence, and online banking, and customer satisfaction are significantly mediated by the perceived value, it is further concluded that service quality dimensions for instance empathy and online banking, and customer satisfaction also mediated by the trust. We have also concluded that services quality dimensions (empathy, reliability, competence, and online banking) and customer satisfaction is moderated by the technology. Thus, the use of technology enhances the customers' satisfaction level significantly. The customers believe that conventional banking sector of Pakistan is aquatinted in a well-versed manner with the changes in technology, and they equipped themselves with the course of time. The technology plays a vital role in order to provide the effective and efficient banking services that enhance the customer satisfaction. Due to technologically integrated system banks can now perform more competitively and efficiently in financial markets. The fast-paced changes in technology have equipped the banks to provide quality services to their customers. The rapid response to technology allows the banking business to ensure the quality services, which eventually confirm the customer satisfaction.

The results of this study are crucial for the decision makers in banking sector of Pakistan, the senior management should realize the importance of new innovative infrastructure of online banking and novel services. They should take the initiatives in order to place the well-equipped information and telecommunication integrated online banking system for their organization. Now, the digitalization is going to take place the conventional banking, therefore, besides the system up gradation, the skills and expertise of human resources are equally imperative in order to run smooth online banking system. Thus, in the light of results of current study, it is suggested to the higher management of Pakistani banks that they must invest on their human resource to convert them into human capital, that human capital is capable to inline their tasks according to the current and future pace of technology. It is also learnt from the results of the study that technology is changing in hours not in months or years, therefore, this is an up hill task to the management of banking sector that they should be very much vigilant and required continuous up gradation and periodic training sessions for their employees on regular basis.

This research is a significant contribution in the application of SERVQUAL model specifically for the banking service quality dimensions and customer satisfaction in marketing research. In our research, we incorporated modified model specific to the banking industry in relation to Pakistan. We have also examined the impact of perceived value and trust as mediating variables by using bootstrapping method, which would be a significant addition in the literature. The most important aspect of this research is 
the introduction of technology as moderating variable amid SERVQUAL dimensions and customer satisfaction. We have established the impact of technology as moderating variable by using moderation and conditional moderation process (Hayes 2012, 2013), which is an important contribution to the literature and this will provide the basis for the future research studies.

The current study has certain limitations for instance, we have selected only Karachi city, and results are the depiction for one city only, thus, some other scholars can take a sample from entire Pakistan, so, the results can further be generalized. We have used collective technology variable as moderating variable; however, it can be further divided into Internet, Fiber optics, speed of processors, smartphones, generation telecommunication technologies $(1 \mathrm{G}-5 \mathrm{G})$ etc. Hence, the results of these individual moderating variables can give the accurate picture of technology use in online banking sector. Finally, we have used only two mediating variables such as perceived value and customers trust. However, other researchers can use the number of other mediating variables to measure the effect of those mediating variable. Lastly, we have used a modified SERVQUAL model and considered four distinctive dimensions, thus, numerous studies have suggested some other dimensions for online banking sector, and ES-QUAL and E-RecSQUAL models for banking and online service industries, so, the future studies could be carried out in light of these limitations.

\section{References}

Abdullah, A. M. A.; Kassim, N. M. 2009. Measuring perceived service quality in Qatari Islamic banks, Journal International Business and Entrepreneurship Development 4(1/2): 90-106. https://doi.org/10.1504/JIBED.2009.022531

Adams, A. M.; Bashiru, M.; Abdulai, I. A. 2016. Customer satisfaction in the banking industry in Ghana: a case of GCB bank limited in Wa municipality, Journal of Social Science Studies 3(2): 217. https://doi.org/10.5296/jsss.v3i2.9528

Al-Hawari, M. 2006. The effect of automated service quality on bank financial performance and the mediating role of customer retention, Journal of Financial Services Marketing 10(3): 228-243. https://doi.org/10.1057/palgrave.fsm.4770189

Ali, M.; Raza, S. A.; Chin-Hong, P. 2015. Factors affecting intention to use Islamic personal financing in Pakistan: evidence from the modified TRA model. MPRA paper number 66023, University library of Munich, Germany.

Amin, M. 2016. Internet banking service quality and its implication on e-customer satisfaction and e-customer loyalty, International Journal of Bank Marketing 34(3): 280-306.

https://doi.org/10.1108/IJBM-10-2014-0139

Amin, M.; Isa, Z. 2008. An examination of the relationship between service quality perception and customer satisfaction: a SEM approach towards Malaysian Islamic banking, International Journal of Islamic and Middle Eastern Finance and Management 1(3): 191-209.

https://doi.org/10.1108/17538390810901131

Amin, M.; Isa, Z.; Fontaine, R. 2011. The role of customer satisfaction in enhancing customer loyalty in Malaysian Islamic banks, The Service Industries Journal 31(9/10): 1519-1532.

https://doi.org/10.1080/02642060903576076

Amin, M.; Isa, Z.; Fontaine, R. 2013. Islamic banks: contrasting the drivers of customer satisfaction on image, trust, and loyalty of Muslim and Non-Muslim customers in Malaysia, International Journal of Bank Marketing 31(2): 79-97. https://doi.org/10.1108/02652321311298627 
Ananth, A.; Ramesh, R.; Prabaharan, B. 2011. Service quality GAP analysis in private sector banks: a customer perspective, Internationally Indexed Journal II(1): 245-252.

Anderson, E. W.; Sullivan, M. W. 1993. The antecedents and consequences of customer satisfaction for firms, Marketing Science 12(2): 125-143. https://doi.org/10.1287/mksc.12.2.125

Anderson, J. C.; Gerbing, D. W. 1988. Structural equation modeling in practice: a review and recommended two-step approach, Psychological Bulletin 103(3): 411-423.

https://doi.org/10.1037/0033-2909.103.3.411

Andreassen, T. W.; Lindestad, B. 1998. Customer loyalty and complex services: the impact of corporate image on quality, customer satisfaction and loyalty for customer with varying degrees of service expertise, International Journal of Service Industry Management 9(1): 7-23.

https://doi.org/10.1108/09564239810199923

Angur, M. G.; Nataraajan, R.; Jahera, Jr. J. S. 1999. Service quality in the banking industry: an assessment in a developing economy, International Journal of Bank Marketing 17(3): 116-125. https://doi.org/10.1108/02652329910269211

Apornak, A. 2017. Customer satisfaction measurement using SERVQUAL model, integration Kano and QFD approach in an educational institution, International Journal of Productivity and Quality Management 21(1): 129-141. https://doi.org/10.1504/IJPQM.2017.083287

Arasli, H.; Katircioglu, S. T.; Mehtap-Smadi, S. 2005. A comparison of service quality in the banking industry, International Journal of Bank Marketing 23(70): 508-526.

https://doi.org/10.1108/02652320510629881

Avkiran, N. K. 1994. Developing an instrument to measure customer service quality in branch banking, International Journal of Bank Marketing 12(6): 10-18.

https://doi.org/10.1108/02652329410063223

Awan, H. M.; Bukhari, K. S.; Iqbal, A. 2011. Service quality and customer satisfaction in the banking sector: a comparative study of conventional and Islamic banks in Pakistan, Journal of Islamic Marketing 2(3): 203-224. https://doi.org/10.1108/17590831111164750

Babakus, E.; Boller, G. W. 1992. An empirical assessment of the SERVQUAL scale, Journal of Business Research 24(3): 253-268. https://doi.org/10.1016/0148-2963(92)90022-4

Bahia, K.; Nantel, J. 2000. A reliable and valid measurement scale for the perceived service quality of banks, International Journal of Bank Marketing 18(2): 84-91.

https://doi.org/10.1108/02652320010322994

Balakrishnan, N.; Barmalzan, G.; Haidari, A. 2016. Multivariate stochastic comparisons of multivariate mixture models and their applications, Journal of Multivariate Analysis 145: 37-43. https://doi.org/10.1016/j.jmva.2015.11.013

Bartlett, M. S. 1954. A note on the multiplying factors for various $\mathrm{x}^{2}$ approximations, Journal of the Royal Statistical Society, Series B (Methodological) 16: 296-298.

Behara, R. S.; Fisher, W. W.; Lemmink, J. G. A. M. 2002. Modelling and evaluating service quality measurement using neural network, International Journal of Operations \& Production Management 22(20): 1162-1185. https://doi.org/10.1108/01443570210446360

Berry, L. L.; Thompson, T. W. 1982. Relationship banking: the art of turning customers into clients, Journal of Retail Banking 4(2): 64-73.

Black, S.; Briggs, S.; Keogh, W. 2001. Service quality performance measurement in public/ private sectors, Managerial Auditing Journal 16(7): 400-405.

https://doi.org/10.1108/EUM0000000005715

Blanchard, R. F.; Galloway, R. L. 1994. Quality in retail banking, International Journal of Service Industry Management 5(4): 5-23. https://doi.org/10.1108/09564239410068670

Boaden, R. J.; Dale, B. G. 1994. A generic framework for managing quality improvement: theory and practice, Quality Management Journal 1(4): 11-29. 
Bourne, P. A. 2016. Customer satisfaction of policing the Jamaican society: using SERVQUAL to evaluate customer satisfaction, Journal of Healthcare Communications 1(3).

https://doi.org/10.4172/2472-1654.100025

Buttle, F. 1996. SERVQUAL: review, critique and research agenda, European Journal of Marketing 30(1): 8-32. https://doi.org/10.1108/03090569610105762

Byrne, B. M. 2009. Structural equation modeling with AMOS, basic concepts, application and programming. $2^{\text {nd }}$ ed. New Jersey: La Erlbaum Associates. https://doi.org/10.4324/9780203805534 Byun, Y. S.; Cho, H. Y. 2017. Effects of CRM success factors on job \& customer performance in banking sectors: focused on the mediating effect of internal member satisfaction, Journal of Distribution Science 15(1): 57-70. https://doi.org/10.15722/jds.15.1.201701.57

Carman, J. M. 1990. Consumer perceptions of service quality: an assessment of the SERVQUAL dimensions, Journal of Retailing 66(1): 33-55.

Caruana, A.; Malta, M. 2002. Service loyalty: the effects of service quality and the mediating role of customer satisfaction, European Journal of Marketing 36(7\&8): 811-828.

https://doi.org/10.1108/03090560210430818

Caruana, A.; Money, A. H.; Berthon, P. R. 2000. Service quality and satisfaction-the moderating role of value, European Journal of Marketing 34(11/12): 1338-1353.

https://doi.org/10.1108/03090560010764432

Chen, S. H.; Hsu, C. C.; Wu, I. P. 2017. The effects of total quality management implications on customer satisfaction and customer loyalty: an empirical study in the Taiwanese security industry, European Journal of Industrial Engineering 11(1): 1-21.

https://doi.org/10.1504/EJIE.2017.081416

Chen, T. Y.; Chang, H. S. 2005. Reducing consumers' perceived risk through banking service quality cues in Taiwan, Journal of Business and Psychology 19(4): 521-539.

https://doi.org/10.1007/s10869-005-4523-5

Cheruiyot, T. K.; Maru, L. C. 2013. Service quality and relative performance of public universities in East Africa, The TQM Journal 25(5): 533-546.

https://doi.org/10.1108/TQM-11-2012-0103

Chi-Cui, C.; Lewis, B. R.; Park, W. 2003. Service quality measurement in the banking sector in South Korea, International Journal of Bank Marketing 21(4): 191-201. https://doi.org/10.1108/02652320310479187

Churchill, G. A. Jr.; Surprenant, C. 1982. An investigation into the determinants of customer satisfaction, Journal of Marketing Research 19 (November): 491-504. https://doi.org/10.2307/3151722

Cronbach, L. J. 1951. Coefficient alpha and the internal structure of tests, Psychometrika16(3): 297-334. https://doi.org/10.1007/BF02310555

Cronin, J. J.; Brady, M. K.; Hult, G. T. 2000. Assessing the effect of quality, value, and customer satisfaction on consumer behavioural intentions in service environments, Journal of Retailing 76(2): 193-218. https://doi.org/10.1016/S0022-4359(00)00028-2

Cronin, Jr. J. J.; Taylor, S. A. 1992. Measuring service quality: a re-examination and extension, The Journal of Marketing 56: 55-68. https://doi.org/10.2307/1252296

Dean, A. M. 2002. Service quality in call centers: implications for customer loyalty, Managing Service Quality 12(6): 414-423. https://doi.org/10.1108/09604520210451894

Fitzsimmons, J. A.; Fitzsimmons, M. J. 2001. Service management: operations, strategy, and information technology. $3^{\text {rd }}$ ed. Singapore: McGraw-Hill Book Co.

Fornell, C.; Larcker, D. F. 1981. Evaluating structural equation models with unobservable variables and measurement error, Journal of Marketing Research 39: 39-50.

https://doi.org/10.2307/3151312 
Garbarino, E.; Johnson, M. S. 1999. The different roles of satisfaction, trust, and commitment in customer relationship, Journal of Marketing 63(2): 70-87. https://doi.org/10.2307/1251946 Gilmore, A. 2003. Service, marketing and management. London: Sage Publication.

Glaveli, N.; Petridou, E.; Liassides, C.; Spathis, C. 2006. Bank service quality: evidence from five Balkan countries, Managing Service Quality 16(4): 380-394.

https://doi.org/10.1108/09604520610675711

Golani, N. 2017. Factors Influencing customer satisfaction \& customer delight in fine dining restaurants, International Journal for Research in Applied Science and Engineering Technology V(II): 629-638. https://doi.org/10.22214/ijraset.2017.2095

Gounaris, S. P. 2005. Trust and commitment influences on customer retention: insights from business-to-business services, Journal of Business Research 58(2): 126-140.

https://doi.org/10.1016/S0148-2963(03)00122-X

Goyal, P.; Chanda, U. 2017. A Bayesian network model on the association between CSR, perceived service quality and customer loyalty in Indian banking industry, Sustainable Production and Consumption 10: 50-65. https://doi.org/10.1016/j.spc.2016.12.001

Gümüş, S.; Öner, G. 2016. Internet banking and customer satisfaction, International Refereed Journal of Research on Economics Management 7(1).

Guo, X.; Duff, A.; Hair, M. 2008. Service quality measurement in the Chinese corporate banking market, International Journal of Bank Marketing 26(5): 306-327.

https://doi.org/10.1108/02652320810894389

Gupta, S.; Zeithaml, V. 2006. Customer metrics and their impact on financial performance, Marketing Science 25(6): 718-739. https://doi.org/10.1287/mksc.1060.0221

Gustafsson, A.; Johnson, M. D., Roos, I. 2005.The effects of customer satisfaction, relationship commitment dimensions and triggers on customer retention, Journal of Marketing 69(4): 210-218. https://doi.org/10.1509/jmkg.2005.69.4.210

Haron, S.; Ahmad, N.; Planisek, S. L. 1994. Bank patronage factors of Muslim and non-Muslim customers, International Journal of Bank Marketing 12(1): 32-40.

https://doi.org/10.1108/02652329410049599

Hayes, A. F. 2012. PROCESS: a versatile computational tool for observed variable mediation, moderation, and conditional process modeling. White paper. Retrieved from http://www.afhayes. com/ public/process2012.pdf

Hayes, A. F. 2013. Introduction to mediation, moderation, and conditional process analysis: a regression-based approach. New York: Guilford Press. http://www.guilford.com/p/hayes3

Haynes, P.; Fryer, G. 2000. Human resources, service quality and performance: a case study, International Journal of Contemporary Hospitality Management 12(4): 240-248.

https://doi.org/10.1108/09596110010330813

Herington, C.; Weaven, S. 2007. Can banks improve customer relationships with high quality online services? Managing Service Quality: An International Journal 17(4): 404-427.

https://doi.org/10.1108/09604520710760544

Hery, H. 2016. A study of customer satisfaction on online trading system application of securities company in Indonesia using SERVQUAL, Communication and Information Technology Journal 9(1): 19-22.

Hoq, M. Z.; Sultana, N.; Amin, M. 2010.The effect of trust, customer satisfaction and image on customers' loyalty in Islamic banking sector, South Asian Journal of Management 17(1): 70-93.

Host, V.; Knie-Andersen, M. 2004. Modeling customer satisfaction in mortgage credit companies, The International Journal of Bank Marketing 22(1): 26-42.

https://doi.org/10.1108/02652320410514915 
Hsieh, Y. C.; Hiang, S. T. 2004. A study of the impacts of service quality on relationship quality in search-experience-credence services, Total Quality Management 15(1): 43-58.

https://doi.org/10.1080/1478336032000149090

Huang, J. H.; Lee, B. C. Y.; Ho, S. H. 2004. Consumer attitude toward grey market goods, International Marketing Review 21(6): 598-614. https://doi.org/10.1108/02651330410568033

Jabnoun, N.; Al-Tamimi, H. A. 2003. Measuring perceived service quality at UAE commercial banks, International Journal of Quality \& Reliability Management 20(4): 458-472.

https://doi.org/10.1108/02656710310468614

Johnson, M. D.; Herrmann, B. A.; Gustafsson, A. 2002. Comparing customer satisfaction across industries and countries, Journal of Economic Psychology 23: 749-769.

https://doi.org/10.1016/S0167-4870(02)00137-X

Jovović, M.; Femić-Radosavović, B.; Lipovina-Božović, M. 2017. Comparative analysis of results of online and offline customer satisfaction \& loyalty surveys in banking services in Montenegro, Journal of Central Banking Theory and Practice 6(2): 65-76.

https://doi.org/10.1515/jcbtp-2017-0013

Kaiser, H. F. 1974. An index of factorial simplicity, Psychometrika 39(1): 31-36. https://doi.org/10.1007/BF02291575

Kholi, A. K.; Jaworski, B. J. 1990. Market orientation: the construct, research propositions, and managerial implications, Journal of Marketing 54(2): 1-18. https://doi.org/10.2307/1251866

Kline, T. J. B.; Sulsky, L. M.; Rever-Moriyama, S. D. 2000. Common method variance and specification errors: a practical approach to detection, The Journal of Psychology 134(4): 401-421. https://doi.org/10.1080/00223980009598225

Kumari, H. V.; Rani, S. 2011. Customer perception of service quality in the retail-banking sector, European Journal of Business and Management 3(3): 299-306.

Kwon, W.; Lee, T. 1994. Measuring SQ in Singapore retail banking, Singapore Management Review 16(2): 1-24.

Ladhari, R.; Ladhari, I.; Morales, M. 2011. Bank service quality: comparing Canadian and Tunisian customer perceptions, International Journal of Bank Marketing 29(3): 224-246.

https://doi.org/10.1108/02652321111117502

Lam, S. S.; Woo, K. S. 1997. Measuring service quality: a test-retest reliability investigation off SERVQUAL, International Journal of Market Research 39(2): 381-396.

Laroche, M.; Taylor, T. 1988. An empirical study of major segmentation issues in retail banking, International Journal of Bank Marketing 6(1): 31-48. https://doi.org/10.1108/eb010824

LeBlanc, G.; Nguyen, N. 1988. Customers' perceptions of service quality in financial institutions, International Journal of Bank Marketing 6(4): 7-18. https://doi.org/10.1108/eb010834

Leech, N. L.; Barrett, K. C.; Morgan, G. A. 2011. SPSS for intermediate statistics: use and interpretation. $4^{\text {th }}$ ed. Lawrence Erlbaum Association Inc. https://doi.org/10.4324/9780203821848 Lehtinen, U.; Lehtinen, J. R. 1991. Two approaches to service quality dimensions, The Service Industries Journal 11(3): 287-303. https://doi.org/10.1080/02642069100000047

Levesque, T.; McDougall, G. H. 1996. Determinants of customer satisfaction in retail banking, International Journal of Bank Marketing 14(7): 12-20. https://doi.org/10.1108/02652329610151340 Lewis, A.; Pescetto, G. 1996. EU and US banking in the 1990s. London: Academic Press.

Lim, P. C.; Tang, N. K. H. 2000. A study of patients' expectations and satisfaction in Singapore hospitals, International Journal of Health Care Quality Assurance 13(7): 290-299.

https://doi.org/10.1108/09526860010378735

Long, P.; Vy, P. D. 2016. Internet banking service quality, customer satisfaction and customer loyalty, International Journal of Strategic Decision Sciences 7(1): 1-7.

https://doi.org/10.4018/IJSDS.2016010101 
Long, S. 2016. The correlation research between express company service quality and undergraduate customer satisfaction degree based on SERVQUAL model, Korean Review of Management Consulting 7(1): 1-23. https://doi.org/10.20434/krmc.2016.02.7.1.1

Lovelock, C. H.; Wirtz, J. 2011. Services marketing: people, technology, strategy. Boston: Prentice Hall.

Manrai, L. A.; Manrai, A. K. 2007. A field study of customers' switching behavior for bank services, Journal of Retailing and Consumer Services 14: 208-215.

https://doi.org/10.1016/j.jretconser.2006.09.005

McDougall, G. H. G.; Levesque, T. 2000. Customer satisfaction with services: putting perceived value into the equation, Journal of Services Marketing 14(5): 392-410.

https://doi.org/10.1108/08876040010340937

McKnight, D. H.; Chervany, N. L. 2002. What trust means in e-commerce customer relationships: an interdisciplinary conceptual typology, International Journal of Electronic Commerce 6(2): 35-59.

Metawa, A. S.; Al-Mossawi, M. 1998. Banking behavior of Islamic bank customers: perspectives and implications, International Journal of Bank Marketing 16(7): 299-313.

https://doi.org/10.1108/02652329810246028

Meyers, L. S.; Gamst, G.; Guarino, A. 2006. Applied multivariate research: design and interpretation. Sage Publications, Inc.

Mishra, A. A. 2016. The role of customer gratitude in relationship marketing: moderation and model validation, Journal of Strategic Marketing 24(6): 529-549.

https://doi.org/10.1080/0965254X.2016.1148762

Mwatsika, C. 2016. Factors influencing customer satisfaction with ATM banking, International Journal of Academic Research in Business and Social Sciences 6(2): 26-41.

https://doi.org/10.6007/IJARBSS/v6-i2/2002

Newman, K. 2001. Interrogating SERVQUAL: a critical assessment of service quality measurement in a high street retail bank, International Journal of Bank Marketing 19(3): 126-139. https://doi.org/10.1108/02652320110388559

Newman, K.; Cowling, A. 1996. Service quality in retail banking: the experience of two British clearing banks, International Journal of Bank Marketing 14(6): 3-11.

https://doi.org/10.1108/02652329610130127

Oliver, R. L. 1980. A cognitive model of the antecedents and consequences of satisfaction decisions, Journal of Marketing Research 17(4): 460-469. https://doi.org/10.2307/3150499

Olsen, L. L.; Johnson, M. D. 2003. Service quality, satisfaction and loyalty: from transactionspecific to cumulative evaluations, Journal of Service Research 5(3): 184-195.

https://doi.org/10.1177/1094670502238914

Oskooii, N.; Albonaiemi, E. 2017. Measuring the customer satisfaction based on SERVQUAL model (case study: Mellat bank in Tehran city), Innovative Marketing 13(2): 13-22.

https://doi.org/10.21511/im.13(2).2017.02

Othman, A Q.; Owen, L. 2002. The multidimensionality of CARTER model to measure customer service quality in Islamic banking industry: a study in Kuwait Finance House, International Journal of Islamic Financial Services 3(1).

Parasuraman, A.; Berry, L. L.; Zeithaml, V. A. 1991. Refinement and reassessment of the SERVQUAL scale, Journal of Retailing 67(4): 420-450.

Parasuraman, A.; Grewall, G. 2000. The impact of technology on the quality-value-loyalty chain: a research agenda, Journal of the Academy of Marketing Science 28(1): 168-174.

https://doi.org/10.1177/0092070300281015 
Parasuraman, A.; Zeithaml, V. A.; Berry, L. L. 1985. A conceptual model of service quality and its implications for future research, The Journal of Marketing 49: 41-50.

https://doi.org/10.2307/1251430

Parasuraman, A.; Zeithaml, V. A.; Berry, L. L. 1988. SERVQUAL: a multiple item scale for measuring consumer perceptions of service quality, Journal of Retailing 64(1): 12-40.

Parasuraman, A.; Zeithaml, V. A.; Berry, L. L. 1994. Alternative scales for measuring service quality: a comparative assessment based on psychometric and diagnostic criteria, Journal of Retailing 70(3): 201-230. https://doi.org/10.1016/0022-4359(94)90033-7

Peterson, R. A.; Wilson, W. R. 1992. Measuring customer satisfaction: fact and artefact, Journal of the Academy of Marketing 20(1): 61-71. https://doi.org/10.1007/BF02723476

Phung, T. B. 2016. The relationships among information systems, knowledge sharing, and customer relationship management in banking industry, International Journal of Electronic Customer Relationship Management 10(1): 65-87. https://doi.org/10.1504/IJECRM.2016.079380

Prasadh R. R.; Suresh, J. 2016. Customer satisfaction index model for Indian banking industry: a qualitative study, Asian Social Science 13(1): 114-129. https://doi.org/10.5539/ass.v13n1p114

Rather, R. A.; Sharma, J. 2017. Customer engagement for evaluating customer relationships in hotel industry, European Journal of Tourism, Hospitality and Recreation 8(1): 1-13.

https://doi.org/10.1515/ejthr-2017-0001

Raza, S. A.; Hanif, N. 2013. Factors affecting internet banking adoption among internal and external customers: a case of Pakistan, International Journal of Electronic Finance 7(1): 82-96. https://doi.org/10.1504/IJEF.2013.051746

Raza, S. A.; Jawaid, S. T.; Hassan, A. 2015. Internet banking and customer satisfaction in Pakistan, Qualitative Research in Financial Markets 7(1): 24-36.

https://doi.org/10.1108/QRFM-09-2013-0027

Reichheld, F. F. 1993. Loyalty-based management, Harvard Business Review 71(2): 64-73.

Robinson, S. 1999. Measuring service quality: current thinking and future requirements, Marketing Intelligence \& Planning 17(1): 21-32. https://doi.org/10.1108/02634509910253777

Rout, B.; Samarpita, S. 2017. Technology of e-banking: customer perception and satisfaction towards public sector banks in Bhubaneswar city, IOSR Journal of Business and Management 19(5): 29-38. https://doi.org/10.9790/487x-1905042938

Rust, R. T.; Oliver, R. L. (Eds.). 1994. Service quality: new directions in theory and practice. London: SAGE Publications, Inc. https://doi.org/10.4135/9781452229102

"Rutherford, G. S. W.; Hair, J. F.; Anderson, R. E.; Tatham, R. L. 1988. Multivariate data analysis, Journal of the Royal Statistical Society. Series D (The Statistician) 37(4/5): 484.

https://doi.org/10.2307/2348783

Ryu, E. 2014. Model fit evaluation in multilevel structural equation models, Journal Frontiers in Psychology 5: 1-9. Article 81. https://doi.org/10.3389/fpsyg.2014.00081

Saroha, R.; Diwan, S. P. 2017. Modelling customer satisfaction and customer loyalty in the frame of telecommunications industry: a review, EuroMed Journal of Management 2(1): 15-37.

https://doi.org/10.1504/emjm.2017.10005179

Selnes, F. 1998. Antecedents and consequences of trust and satisfaction in buyer-seller relationship, European Journal of Marketing 32(3/4): 305-322. https://doi.org/10.1108/03090569810204580

Setiawan, H.; Sayuti, A. J. 2017. Effects of service quality, customer trust and corporate image on customer satisfaction and loyalty: an assessment of travel agencies customer in South Sumatra Indonesia, IOSR Journal of Business and Management 19(5): 31-40.

https://doi.org/10.9790/487x-1905033140

Seyal, A. 2011. Determinants of e-banking among Bruneian corporate customers: an application of theory of planned behavior, International Journal of E-Adoption 3(4): 13-28.

https://doi.org/10.4018/jea.2011100102 
Singh, J.; Sirdeshmukh, D. 2000. Agency and trust mechanisms in customer satisfaction and loyalty judgments, Journal of the Academy of Marketing Science 28(1): 150-167.

https://doi.org/10.1177/0092070300281014

Smith, A. M. 1995. Measuring service quality: is SERVQUAL now redundant?, Journal of Marketing Management 11(1-3): 257-276. https://doi.org/10.1080/0267257X.1995.9964341

Smith, A. M.; Lewis, B. R. 1988. Customer care in the service sector: the supplier's perspective. FSRC, Manchester: Manchester School of Management.

Smith, A. M.; Lewis, B. R. 1989. Customer care in financial service organisations, International Journal of Bank Marketing 7(5): 13-22. https://doi.org/10.1108/02652328910131917

Smith, R. A.; Houston, M. J. 1982. Script-based evaluations of satisfaction with services, in L. Berry, G. Shostack, G. Upah (Eds.), Emerging Perspective on Services Marketing. AMA, Chicago, IL: 59-62

Stehling, F.; Moormann, J. 2002. Strategic positioning of e-commerce business models in the portfolio of corporate banking, in Proceedings of the $35^{\text {th }}$ Hawaii International Conference on System Sciences (HICSS-35"02), Hawaii, USA, 1-10.

Talmor, S. 1995. New life for dinosaurs, The Banker 145(September): 75-78.

Tan, L. H.; Chew, B. C.; Hamid, S. R. 2016. Relationship between service quality and customer satisfaction: a study of Malaysian banking industry, International Journal of Productivity and Quality Management 19(1): 38-50. https://doi.org/10.1504/IJPQM.2016.078008

Taylor, S. A.; Baker, T. L. 1994. An assessment of the relationship between service quality and customer satisfaction in the formation of consumers' purchase intentions, Journal of Retailing 70(2): 163-178. https://doi.org/10.1016/0022-4359(94)90013-2

Teas, R. K. 1993.Expectations, performance evaluation, and consumers' perceptions of quality, The Journal of Marketing 57: 18-34. https://doi.org/10.2307/1252216

Tilston, D. 1989. Making progress in quality financial services - European retail finance for the 1990s. London: PA Consulting Group, The Economist Publications.

Verma, K. 2016. Importance performance analysis and SERVQUAL model: an integrated approach for enhancing customer satisfaction, Review of Professional Management-A Journal of New Delhi Institute of Management 14(1): 51-59.

https://doi.org/10.20968/rpm/2016/v14/i1/109406

Wang, Y.; Lo, H. P.; Hui, Y. V. 2003. The antecedents of service quality and product quality and their influences on bank reputation: evidence from the banking industry in China, Managing Service Quality: An International Journal 13(1): 72-83.

Wilkinson, A.; Allen, P.; Snape, E. 1991.TQM and the management of labour, Employee Relations 13(1): 24-31. https://doi.org/10.1108/01425459110002349

Woodside, A. G.; Frey, L. L.; Daly, R. T. 1989. Linking service quality, customer satisfaction, and behavioral intention, Journal of Health Care Marketing 9: 5-17.

Yang, Z.; Jun, M.; Peterson, R. T. 2004. Measuring customer perceived online service quality: scale development and managerial implications, International Journal of Operations \& Production Management 24(11): 1149-1174. https://doi.org/10.1108/01443570410563278

Yavas, U.; Bilgin, Z.; Shemwell, D. J. 1997. Service quality in the banking sector in an emerging economy: a consumer survey, International Journal of Bank Marketing 15(6): 217-223.

https://doi.org/10.1108/02652329710184442

Yoo, D. K.; Park, J. A. H. 2007. Perceived service quality: analyzing relationships among employees, customers, and financial performance, International Journal of Quality \& Reliability Management 24(9): 908-926. https://doi.org/10.1108/02656710710826180 
Zavareh, F. B.; Ariff, M. S. M.; Jusoh, A.; Zakuan, N.; Bahari, A. Z.; Ashourian, M. 2012. E-service quality dimensions and their effects on e-customer satisfaction in internet banking services, Procedia - Social and Behavioral Sciences 40: 441-445.

https://doi.org/10.1016/j.sbspro.2012.03.213

Zeithaml, V. A. 1988. Consumer perceptions of price, quality, and value: a means-end model and synthesis of evidence, Journal of Marketing 52: 2-22. https://doi.org/10.2307/1251446

Zeithaml, V. A.; Bitner, M. J.; Gremler, D. D. 2009. Services marketing: integrating customer focus across the firm. $5^{\text {th }}$ ed. New York: McGraw-Hill.

Zhu, F. X.; Wymer, W.; Chen, I. 2002. IT-based services and service quality in consumer banking, International Journal of Service Industry Management 13(1): 69-90.

https://doi.org/10.1108/09564230210421164

Rizwan Raheem AHMED is a Professor at the Faculty of Management Sciences, Indus University, Pakistan, and obtained PhD from Hamdard University. During his research career of more than 12 years, he mainly focused on marketing strategy, digital marketing, organizational performance, behaviour of stocks, money market portfolios and Liquidity market problems by using Time Series analysis models, Multivariate Regression, CFA and EFA models. Besides, he also made a significant research in current issues related to Sales \& Marketing of local and global Pharmaceutical Industry; he used quantitative \& qualitative models for this purpose. His research papers have already published in Technological and Economic Development of Economy, Economic Research-Ekonomska Istraživanja, Amfiteatru Economic, and Transformations in Business \& Economics.

Jolita VVEINHARDT is a Chief Researcher and Professor at the Faculty of Economics and Management, Vytautas Magnus University, and holds $\mathrm{PhD}$ from Vytautas Magnus University in Lithuania. Dr Jolita Vveinhardt has published over 100 peer-reviewed papers focused on mobbing in employee relations, organizational climate, and nepotism as a management anomaly, values congruence, human resource management, corporate social responsibility, and the knowledge-based economy. Her publications have appeared in the Journal of Business Economics and Management, Transformations in Business and Economics, Engineering economics and Problems and Perspectives in Management among others.

Dalia ŠTREIMIKIENĖ is a Principal Research Fellow at Vilnius University, Kaunas Faculty, Lithuania, and holds PhD from Vilnius Gediminas Technical University, Lithuania. Prof. Dr Dalia Štreimikienè has published over 200 peer-reviewed papers on multi-criteria decision-making, efficiency analysis, and energy and agricultural economics in such outlets as Applied Energy, Energy Policy, Renewable and Sustainable Energy Reviews.

Muhammad ASHRAF is a visiting Lecturer and Research Scholar at Faculty of Management Sciences, Indus University, Pakistan. He obtained his MS (Management) degree from Indus University; he is also research associate and coordinator for Indus Journal of Management Sciences (IJMS). His research area is human resource management, and special emphasis on training \& development, compensation, performance appraisal, and succession planning. He has presented number of research papers in national and international conferences, and also appeared more than 20 research papers on the topic of HRM \& general management have been published in national and international reputed journals.

Zahid Ali CHANNAR is an Associate Professor, at Department of Business Administration, Sindh Madressatul Islam University, Pakistan. He obtained PhD from ISRA University, Hyderabad. During his broad research career of more than 20 years, he mainly focused on human research management, organizational development, training and development, marketing and general management. Besides, he also made a significant contribution of research for private sector employees' and Organizational related issues; he used quantitative models for these studies. He has more than 25 research papers in national and international reputed journals. He has also presented several research papers in national and international conferences. 